\title{
Taxonomic review of the Neotropical genus Neopachylus (Arachnida, Opiliones, Gonyleptidae)
}

\author{
Vivian Moreira Montemor'ㄹ, Cibele Bragagnolo² \& Ricardo Pinto-da-Rocha'
}

1. Departamento de Zoologia, Instituto de Biociências, Universidade de São Paulo, Caixa Postal 11.461, 05422-970 São Paulo, SP, Brazil. (ricrocha@usp.br) 2. Departamento de Ciências Exatas e da Terra, Universidade Federal de São Paulo, Rua Prof. Arthur Riedel, 275, 09972-270 Diadema, SP, Brazil.

\begin{abstract}
A taxonomic review of the genus Neopachylus Roewer, 1913 together with keys to the species for both males and females are presented. Gephyropachylus marginatus Mello-Leitão, 1931 is considered a junior subjective synonym of Neopachylus serrinha Soares \& Soares, 1947, and Huralvius incertus Mello-Leitão, 1935 is considered a synonym of Neopachylus nebulosus (Mello-Leitão, 1936). This genus is restricted to southern Brazil, occurring in states of Paraná, Santa Catarina and Rio Grande do Sul.
\end{abstract}

KEYWORDS. Atlantic Rainforest, harvestmen, taxonomy.

RESUMO. Revisão taxonômica do gênero Neotropical Neopachylus (Arachnida, Opiliones, Gonyleptidae). Uma revisão taxonômica de Neopachylus Roewer 1913, juntamente com chaves para determinação de espécies com base em machos e fêmeas, são apresentadas. Duas espécies, ambas descritas por fêmeas, foram sinonimizadas: Gephyropachylus marginatus Mello-Leitão, 1931, considerado como sinônimo-júnior de Neopachylus serrinha Soares \& Soares, 1947; e Huralvius incertus Mello-Leitão, 1935, considerado como sinônimo-júnior de Neopachylus nebulosus (MelloLeitão, 1936). O gênero está restrito ao sul do Brasil (Paraná, Santa Catarina e Rio Grande do Sul).

PALAVRAS-CHAVE. Mata Atlântica, opiliões, taxonomia.

Gonyleptidae is the most diverse family within Laniatores with more than 800 nominal species in 16 subfamilies (KURY, 2013), all Neotropical and mostly from the Brazilian Atlantic Rainforest. Pachylinae is the largest subfamily in Gonyleptidae, with 129 genera and 400 described species (KURY, 2003). The subfamily is considered polyphyletic, based on morphological (PINTODa-Rocha, 2002; Da Silva \& Pinto-Da-Rocha, 2010; Mendes, 2011; Bragagnolo \& Pinto-da-Rocha, 2012; Hara et al., 2012), phenotypic (Caetano \& Machado, 2013) and molecular data (PinTO-DA-RochA et al., 2014).

Neopachylus was proposed by RoEwer (1913) to include N. bellicosus Roewer, 1913. The same author in 1915, described N. mamillosus Roewer, 1915. Later, Mello-Leitão (1931) described three species in monotypic genera: Gephyropachylus marginatus Mello-Leitão, 1931 (in Tricommatinae), Huralvius incertus Mello-Leitão, 1935 and Nunduavius nebulosus Mello-Leitão, 1936 (both in Pachylinae). The descriptions of G. marginatus and $H$. incertus, were based on females only. Soares \& SoAres (1945) described N. herteli Soares \& Soares, 1945, and two years later they described $N$. serrinha Soares \& Soares, 1947 and N. imaguirei Soares \& Soares, 1947. In the same year, a key for the species of Neopachylus was published by SoARes \& SoARes (1947b). The last species to be described in the genus was Neopachylus taioensis Soares, 1966. KURY (2003), in his catalogue of the New World Laniatores, synonymized Gephyropachylus, Huralvius and Nunduavius with Neopachylus, and the genus is currently composed of nine species. KURY (2003) pointed out that Neopachylus species are very similar to each other and suggested a revision of the genus. The purpose of this paper is the taxonomic review of the genus Neopachylus.

\section{MATERIAL AND METHODS}

Material examined. The revision was based on 309 specimens, including all valid species of the genus. The acronyms of institutions and their depository are listed below: SMF (Naturmuseum Senckenberg Sektion Arachnologie, Frankfurt, curator: P. Jäger); MHNCI (Museu de História Natural Capão da Imbuia, Curitiba, curator: J. Leite); MCN (Museu de Ciências Naturais da Fundação Zoobotânica, Rio Grande do Sul, Porto Alegre, curator: R. Ott); MNRJ (Museu Nacional da Universidade Federal do Rio de Janeiro, Rio de Janeiro, curator: A. B. Kury); IBSP (Instituto Butantan, São Paulo, curator: A. D. Brescovit); MZSP (Museu de Zoologia da Universidade de São Paulo, São Paulo, curator: R. Pinto-da-Rocha); CGPC (Privative Collection Mr. Carlos Nicolau Gofferjé, Santa Catarina), incorporated to the Museu de Zoologia (MZSP) in 2009.

Descriptions and illustrations. The descriptions are presented in alphabetical order and, with the exception of $N$. bellicosus, were based on the type material. Terminology follows Acosta et al. (2007), with the following exceptions proposed by Bragagnolo \& Pinto-Da-Rocha (2012): granules are considered tegumentary microstructures smaller than $0.01 \mathrm{~mm}$. The term armature refers to large regions of body/legs and are classified as: (1) apophyseshigh projections (normally higher than wide) with thinner or blunt tips, with no clear boundary with the surrounding cuticle, 2) setae-processes with thin apex and inserted in a socket (occur on pedipalps and penis), (3) tubercles-small projections without clear limit with the surrounding cuticle, normally as wide as high, apically thinner or cylindrical in all its extension and (4) a region is considered armed when one or two projections are higher/larger than any 
other in the same region. Terminology for the macrosetae of the ventral plate follows KURY \& VillarREAL (2015).

A new term, rippled elevation, is created to describe the structure, present on scutal areas III-IV and free tergites in some Neopachylus species, that is higher than a tubercle, but lower than an apophysis. The terminology for pedipalpal setation length follows PINTO-DA-RocHA (1997). The females are described only insofar as they differ from the males.

Illustrations of external morphology were made using a Leica Leo 440 stereomicroscope with a camera lucida. The method of preparing the penis follows PINTODA-Rocha (1997). Type measurements are in millimeters. Abbreviations in synonymy listing: cat, catalogue; cit, citation; descr, description; rdesc, redescription; syst, systematic. Abbreviations in descriptions: SL, scutum length; SMW, maximum scutum width; HOA, height of the ocularium apophysis; RPT, retrolateral apophysis bifid with prolateral stem short and truncated.

Distribution maps of the species: we used the computer software DIVA-GIS version 7.1.1.1 (HiJMANS et al., 2004) to make a map of where each species occurs. The records of geographical distribution were taken from the labels of the examined materials. The coordinates of geographical records were obtained from data banks available on the Internet: http://geonames.nga.mil/ and http://www.fallingrain.com/world/index.html (Directory of Cities and Towns in World - Global Gazetteer - version 2.2).

\section{RESULTS AND DISCUSSION}

Key to males of Neopachylus species

1. Areas III and IV of dorsal scutum with strong paramedian rounded smooth tubercles (Figs $1 ; 5 ; 7 ; 8 ; 12 ; 14$ ) ... 2

Areas III and IV of dorsal scutum with paramedian oval rippled elevations (Figs $2-4 ; 6 ; 9 ; 10 ; 11 ; 13$ ) ..... . 4

2. Ocularium with single long pointed apophysis (higher than the ocularium height) (Figs $8 ; 9 ; 14) \ldots \ldots \ldots \ldots \ldots \ldots . . . \ldots 3$

Ocularium with single short pointed apophysis (lower than the ocularium height) (Figs 5; 12)

............................. nebulosus (Mello-Leitão, 1936)

3. Areas I-IV of dorsal scutum with few scattered tubercles (Fig. 7); femur IV with two dorsobasal rounded apophyses geminated at base, without retrolateral basal spiniform apophysis (Figs. 33-35) .

N. taioensis Soares, 1966

Areas I-IV of dorsal scutum densely covered by tubercles (Fig. 1); femur IV without dorsobasal rounded apophysis geminated at base, with retrolateral basal spiniform apophysis (Figs. 15-17)

N. bellicosus Roewer, 1913

4. Oval rippled elevations on areas III/IV of dorsal scutum with three or less ripples by elevation; posterior margin of dorsal scutum with one row of rounded tubercles (Figs 6; 13) ...... N. serrinha Soares \& Soares, 1947

Oval rippled elevations on areas III/IV of dorsal scutum with five or more ripples by elevation; posterior margin of dorsal scutum with oval rippled elevations (Figs 2-4; 9-11)

5. Area IV of dorsal scutum with two pairs of oval rippled elevations on each side; posterior margin of dorsal scutum with a median row of eight to ten oval rippled elevations (Fig. 2)

$N$. herteli Soares \& Soares, 1945

Area IV of dorsal scutum with one pair of oval rippled elevations on each side; posterior margin of dorsal scutum with six oval rippled elevations, grouped on each side (Figs 3; 4)

6. Lateral margins of dorsal scutum with one row of rounded tubercles of the same size, beginning at the anterior groove of area I and reaching the posterior margin of dorsal scutum (Figs 3; 10); coxa IV with prolateral apical apophysis bifid with dorsal stem slightly longer than the ventral stem (Figs $3 ; 39$ ) ...... ....................... N. imaguirei Soares \& Soares, 1947

Lateral margins of dorsal scutum with one row of rounded tubercles, beginning at the anterior groove of area II and reaching the posterior margin of dorsal scutum, increasing in size medially (Figs 4; 11); coxa IV with prolateral apical apophysis bifid with dorsal stem two times longer than the ventral stem (Figs 4; 40) ........... N. mamillosus Roewer, 1915

Key to females of Neopachylus species

The females have the same aspect as males regarding the coloration, ocularium apophysis and quantity and disposition of tubercles. However, there is sexual dimorphism in the armature of areas III-IV of dorsal scutum, posterior margin and free tergites, which is reduced. The armature of legs IV is also reduced in females, coxa with a small apical prolateral spiniform apophysis, remaining segments unarmed (except $N$. taioensis). Females of Neopachylus herteli and Neopachylus mamillosus are unknown.

1. Lateral margins of dorsal scutum with one row of rounded tubercles (Figs 62-65); femur IV unarmed, recovered by small tubercles ................................. 2

Lateral margins of dorsal scutum with an elevation near the groove of area II (Fig. 66); femur IV with dorsal and retrolateral small spiniform apophysis (Figs 69; 70) N. taioensis Soares, 1966

2. A pair of small rounded paramedian tubercles on areas I, II, III and IV of dorsal scutum, similar in size and shape (Fig. 65) .... N. serrinha Soares \& Soares, 1947

A pair of rounded paramedian tubercles in areas I, II, III and IV of dorsal scutum, being the III and IV enlarged (Figs 62-64) .......................................... 3

3. Posterior margin of dorsal scutum with a par of enlarged median rounded tubercles (Figs 62; 63) ................. 4

Posterior margin of dorsal scutum with one row of rounded tubercles with the same size (Fig. 64) .... 

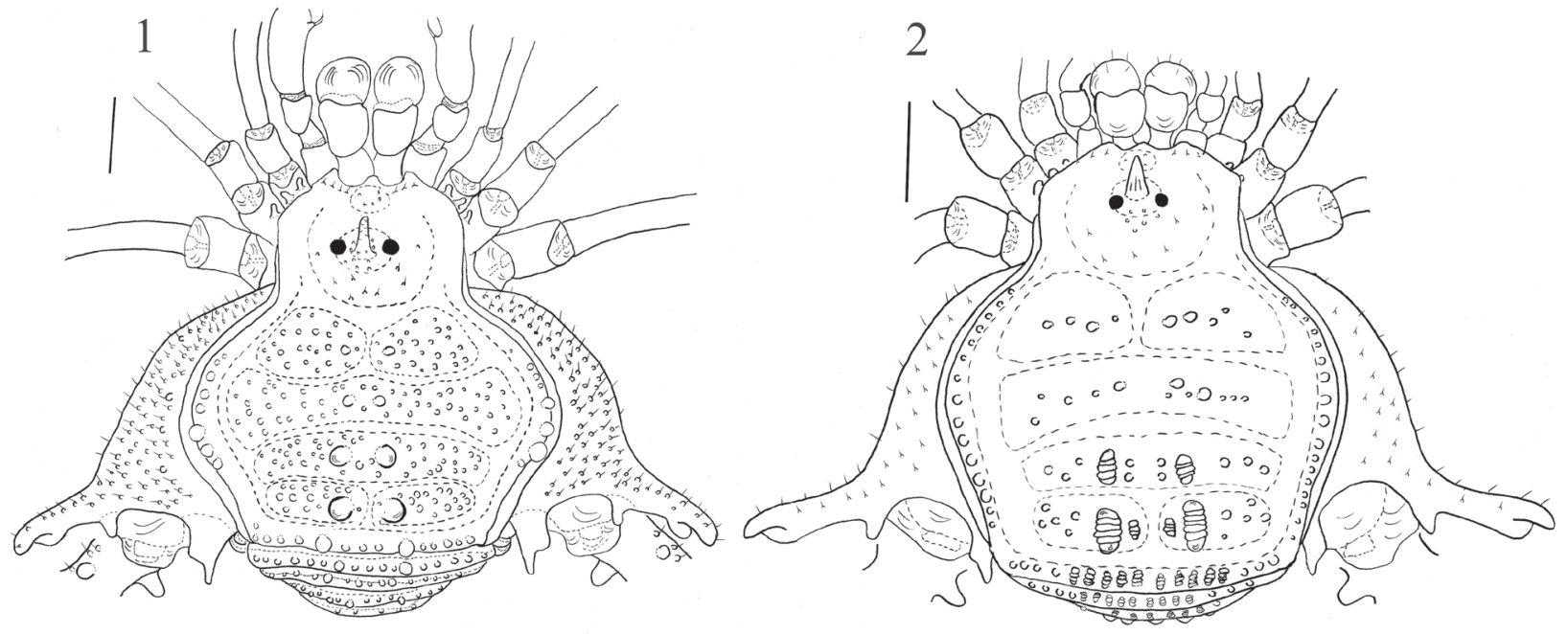

3

4
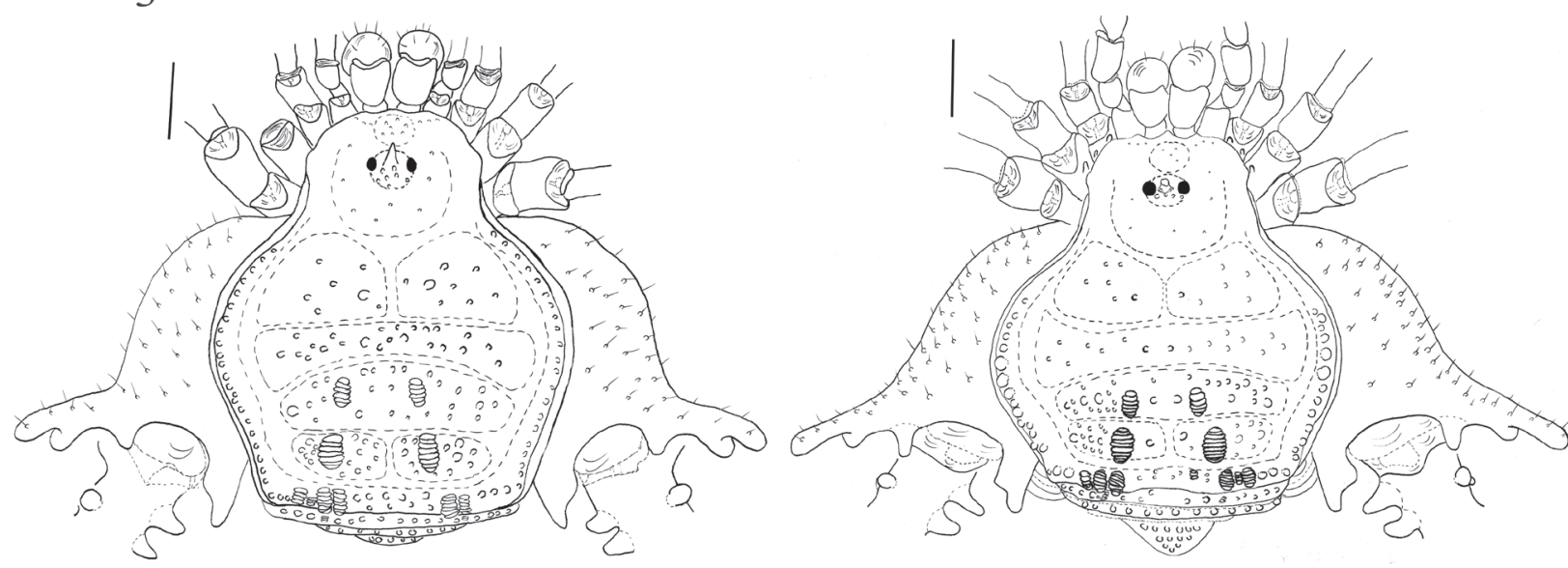

Figs 1-4. Habitus, dorsal view of males of Neopachylus: 1, N. bellicosus (MZSP 30815); 2, N. herteli (MZSP 1632); 3, N. imaguirei (MZSP 1751); 4, N. mamillosus (SMF 1095). Scale $1 \mathrm{~mm}$.

N. nebulosus (Mello-Leitão, 1936)

4. Lateral margins of dorsal scutum with enlarged tubercles on area II; coxa IV as wide as trochanter IV, in dorsal view (Fig. 62) . N. bellicosus Roewer, 1913

Lateral margins of dorsal scutum with tubercles of the same size; coxa IV twice as wide as the trochanter IV width, in dorsal view (Fig. 63)

N. imaguirei Soares \& Soares, 1947

\section{Neopachylus Roewer, 1913}

Neopachylus Roewer, 1913:58 [desc đ̋]; 1923:414 [rdesc; key]; 1929:185 [key]; Mello-Leitão, 1923:119 [cit]; 1926:341 [cit]; 1932:192 [rdesc]; 1933:135 [cit]; 1935a:100 [cit]; 1937:291 [cit]; SoARES \& SOARES, 1947b:224 [key]; 1954:278 [cit]; MuÑoz-CuEvas, 1973:226 [cit]; TAVARES, 1980:156 [cit]; KURY, 1995:316 [syst]; $2003: 178$ [cat]. (Type species Neopachylus bellicosus Roewer, 1913, by monotypy).

Gephyropachylus Mello-LeITÃo, 1931:13 [desc]; 1932:440 [rdesc]; 1935a:94 [key]; 1938:143 [cit]; RamBLa, 1978:304 [cit]; KURY, 2003:178 [cat]. (Type species Gephyropachylus marginatus Mello-
Leitão, 1931, by original designation). Synonymized by KURY (2003). Huralvius Mello-Leitão, 1935a:382 [desc]; SoAREs \& SoARES, 1954:268 [rdesc]; KuRY, 1995: 316 [cit]; 2003:178 [cat]. (Type species Huralvius incertus, Mello-Leitão, 1935a, by original designation). Synonymized by KuRY (2003).

Xuraloius Mello-Leitão, 1935b:101 [cit] (misspelling).

Nunduavius Mello-Leitão, 1936:10, fig. 8 [desc]; Soares \& Soares, 1954:279 [rdesc]. (Type species Nunduavius nebulosus Mello-Leitão, 1936, by original designation). Synonymized by KuRY (2003).

Diagnosis. Dorsal scutum pyriform. Ocularium with a single spiniform apophysis, directed frontwards. Scutal areas I and IV divided by longitudinal groove; II and III undivided; areas III/IV with a par of strong paramedian rounded tubercles or oval rippled elevations. Posterior margins of dorsal scutum and free tergites with one row of small rounded tubercles or oval rippled elevations. Coxa IV with one prolateral apical apophysis blunt and bifid, one median subapical apophysis rounded, one retrolateral apophysis bifid with prolateral stem short and truncated 

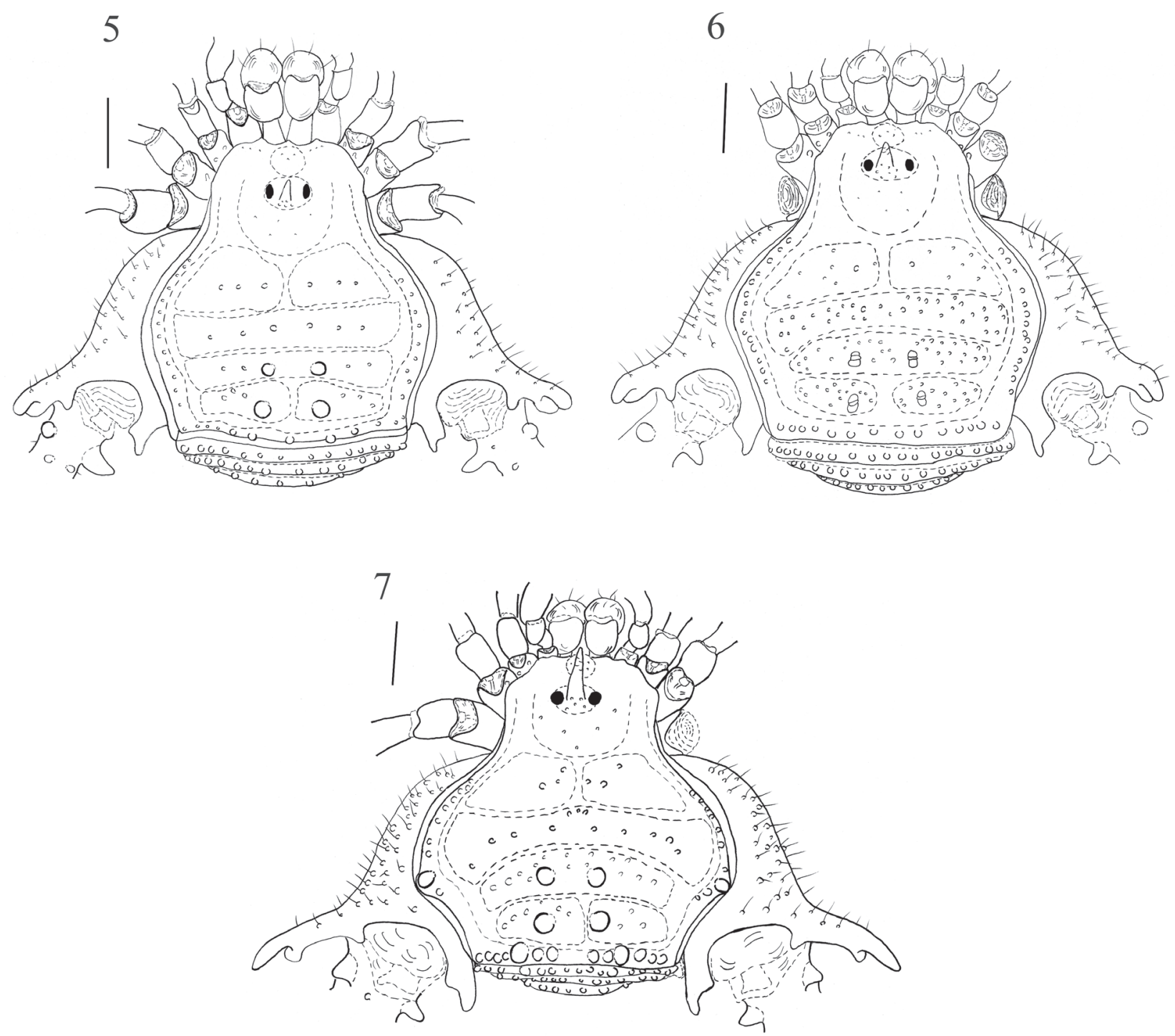

Figs 5-7. Habitus, dorsal view of males of Neopachylus: 5, N. nebulosus (MNRJ 42276); 6, N. serrinha (MZSP 1769); 7, N. taioensis (MZSP 1339). Scale $1 \mathrm{~mm}$.

(type RPT). Trochanter IV rectangular, with two prodorsal, two retrodorsal and 3-5 retrolateral apophyses (Fig. 36). Penis: ventral plate with distal and lateral margins concave, three pairs $\mathrm{C} 1-\mathrm{C} 3$ of latero-distal macrosetae, three pairs A1-A3 of latero-basal macrosetae, one pair on reduced macrosetae $\mathrm{B}$ clustered with $\mathrm{A}$, more ventrally inserted, one pair D1 of lateral macrosetae between A and C; two pairs of reduced macrosetae E1-E2 on latero-distal flange; stylus with long stem, straight, subdistal filaments and ventral process almost parallel and smaller than stylus, thin, with apex curved downwards, serrate or smooth.

Geographical distribution (Fig. 71). Restricted to the Brazilian Southern Atlantic Forest, in states of Paraná, Santa Catarina and Rio Grande do Sul.

\section{Neopachylus bellicosus Roewer, 1913}

(Figs $1 ; 8 ; 15-17 ; 37 ; 44-46 ; 62 ; 71$ )

Neopachylus bellicosus RoEwer, 1913:58, figs 25-26 [desc 3̉]; 1923:415, figs 514-515 [key]; Mello-Leitão, $1923: 119$ [cit]; 1932:192, fig. 106 [desc]; Soares \& Soares, 1947b:224 [key]; 1954:278 [cit]; WeIDNER, 1959:127 [cit]; AcosTA, 1996:219 [cit]; KuRY, 2003:178 [cat]. (Type material: ZMH, $\widehat{\partial}$, + paralectotypes; SMF RI 807, $\widehat{\partial}$ lectotype; SMF RI 814, $2 \hat{\jmath}$ paralectotypes; SMF RI 786, $2 \hat{\jmath}, 2$ 우 paralectotypes; SMF examined; ZMH not examined. Type locality: Brazil, Rio Grande do Sul, Porto Alegre).

Diagnosis: Similar to N. nebulosus e N. taioensis in the armature of areas III and IV with a pair of large rounded paramedian tubercles. It can be distinguished from $N$. nebulosus by the lateral margin of dorsal scutum with a row of rounded tubercles, enlarged close to area II (Figs $1 ; 8)$ and from $N$. taioensis by the presence of a spiniform 
8

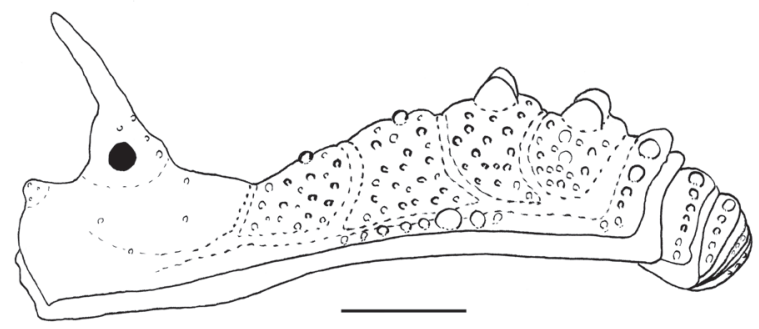

10

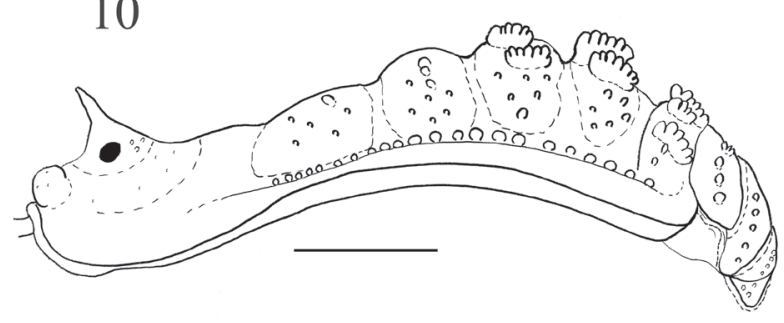

12

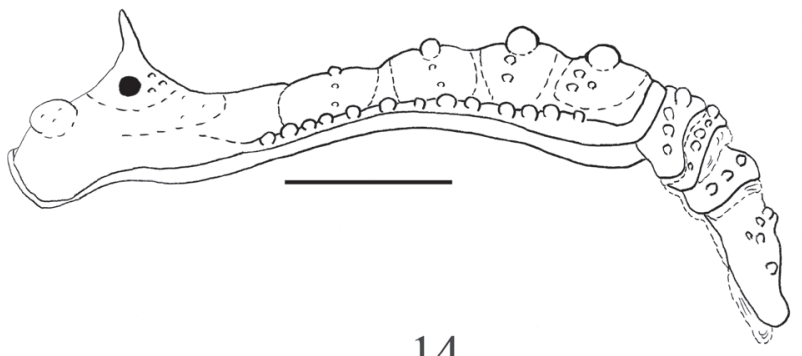

14
9

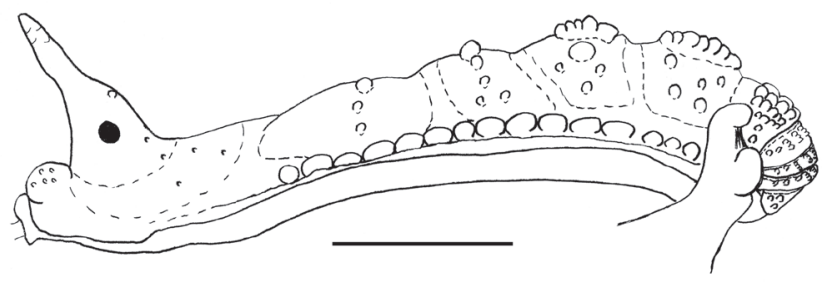

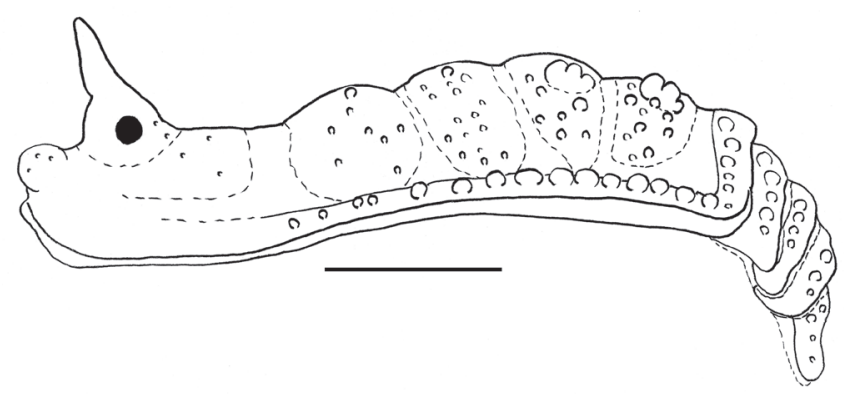

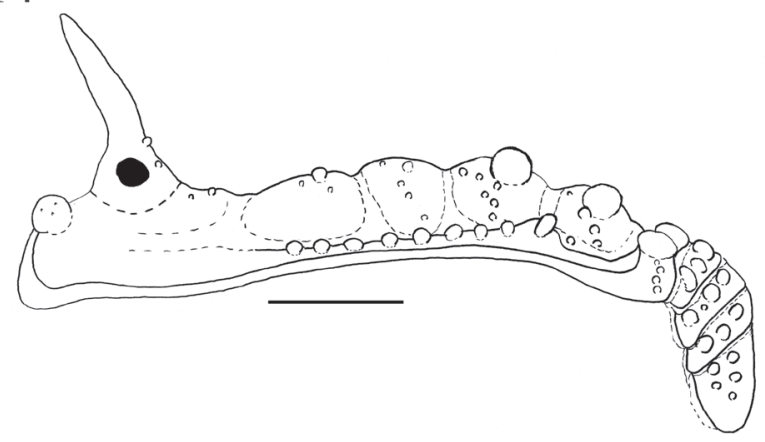

Figs 8-14. Habitus, lateral view of males of Neopachylus: 8, N. bellicosus (MZSP 30815); 9, N. herteli (MZSP 1632); 10, N. imaguirei (MZSP 1751); 11, N. mamillosus (SMF 1095); 12, N. nebulosus (MNRJ 42276); 13, N. serrinha (MZSP 1769); 14, N. taioensis (MZSP 1339). Scale 1 mm.

retrolateral basal apophysis on femur IV (Figs 15-17) and absence of a geminate dorsobasal apophysis on femur IV.

Male (MZSP 30815). Measurements: SL 5.05; SMW 5.25; femur I 1.80; femur II 4.75; femur III 3.80; femur IV 6.00; HOA: $1.2 \mathrm{~mm}$. Dorsum (Figs 1; 8): Ocularium with a single median long apophysis, slightly directed anteriorly with 11 small scattered tubercles on base. Carapace with nine small scattered tubercles. Lateral margins of dorsal scutum with 7-8 rounded tubercles, beginning at the posterior groove of area I and reaching anterior groove of area III; with enlarged tubercles near area II. Area I with a pair of slightly enlarged paramedian tubercles and 22 smaller scattered tubercles on each side. Area II with a pair of slightly enlarged paramedian tubercles and 51 smaller tubercles uniformly distributed. Area III with a pair of robust, rounded paramedian tubercles and 42 smaller tubercles, uniformly distributed. Area IV with 
15

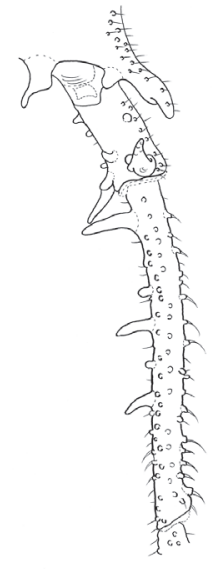

18

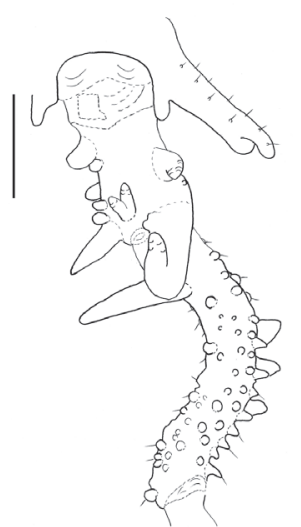

21

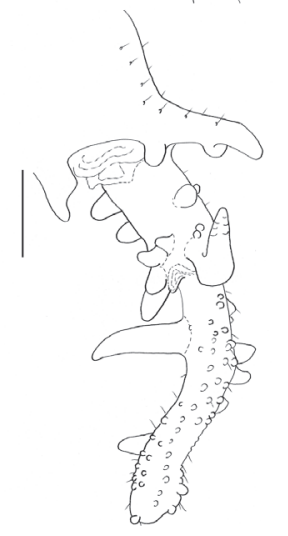

24

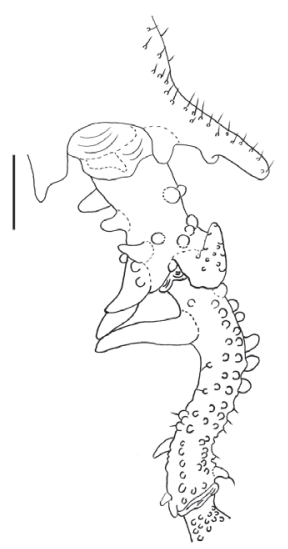

16

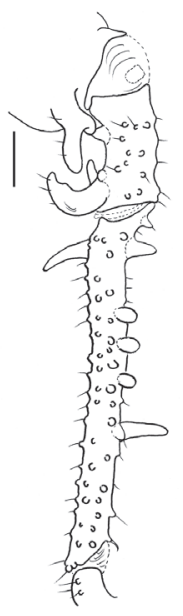

19

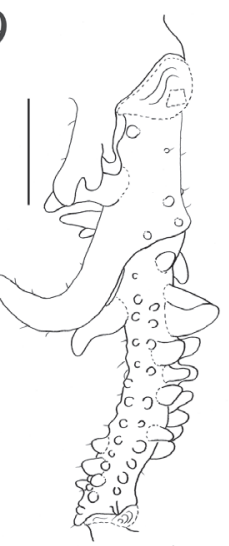

22

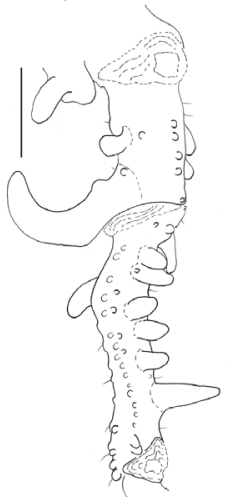

25

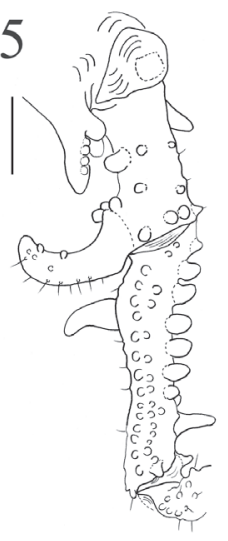

17

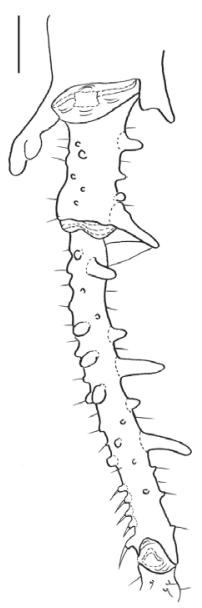

20

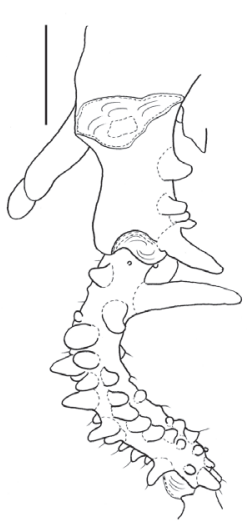

23

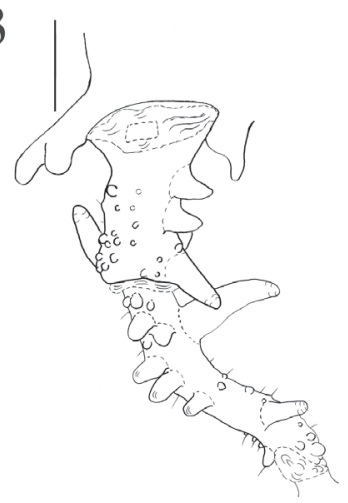

26

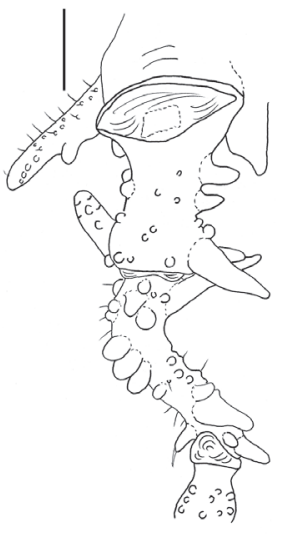

Figs 15-26. Leg IV of males of Neopachylus, coxa apex, trochanter and femur. Figs15-17, N. bellicosus (MZSP 30815): 15, dorsal view, 16, lateral view, 17, ventral view; 18-20, $N$. herteli (MZSP 1632): 18, dorsal view, 19, lateral view, 20, ventral view; 21-23, N. imaguirei (MZSP 1751): 21, dorsal view, 22, lateral view, 23, ventral view; 24-26, N. mamillosus (SMF 1095): 24, dorsal view, 25, lateral view, 26, ventral view. Scale $1 \mathrm{~mm}$. 
27

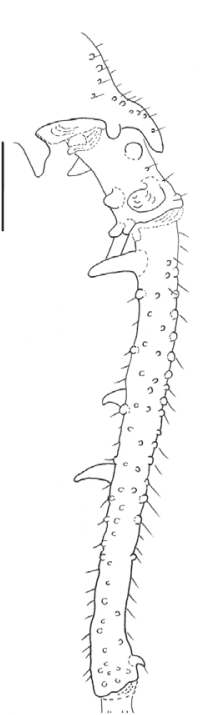

30

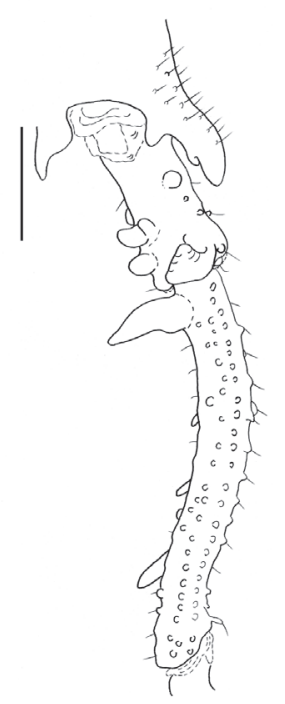

33

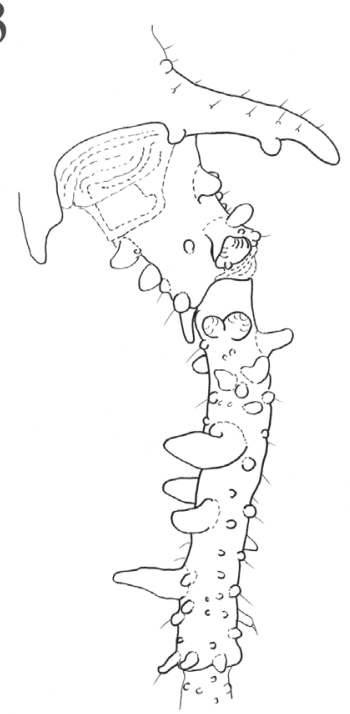

28

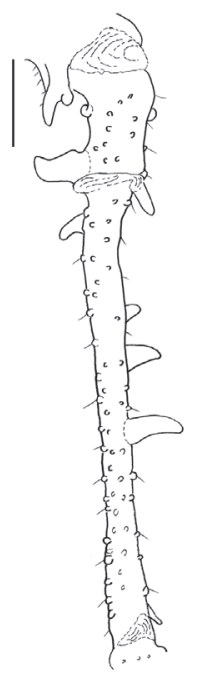

31

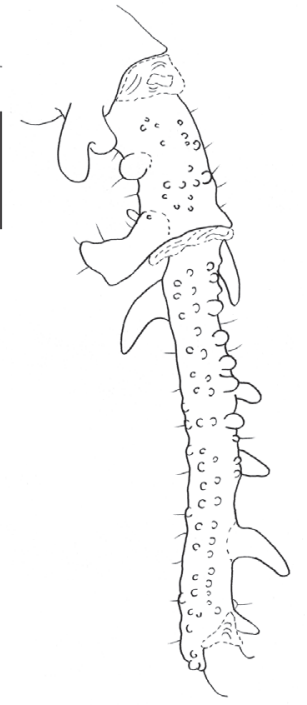

34

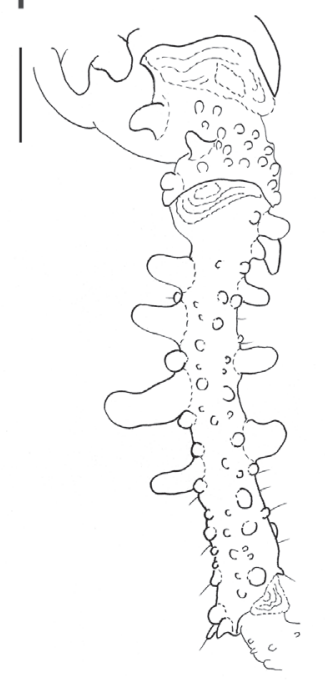

29

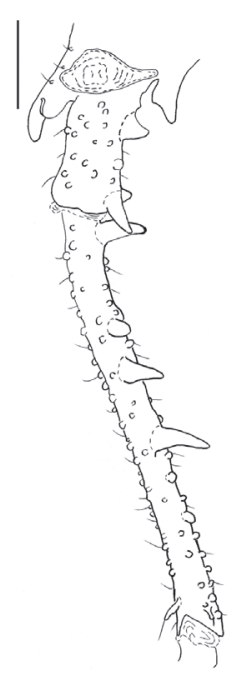

32

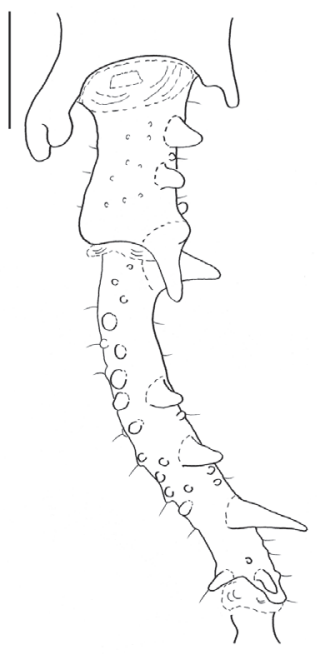

35

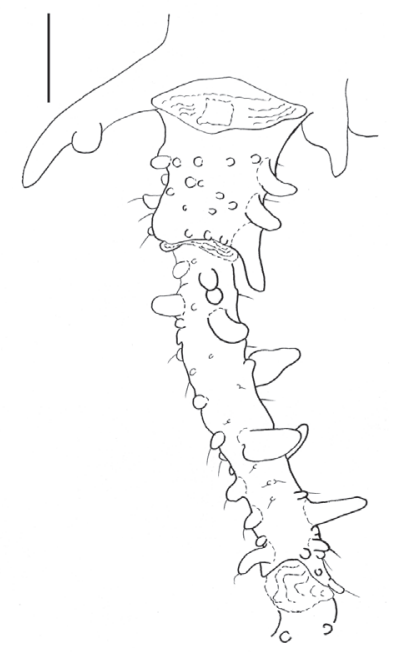

Figs 27-35. Leg IV of males of Neopachylus, coxa apex, trochanter and femur. Figs 27-29, N. nebulosus (MNRJ 42276): 27, dorsal view, 28, lateral view, 29, ventral view. 30-32, N. serrinha (MZSP 1769): 30, dorsal view, 31, lateral view, 32, ventral view. 33-35, N. taioensis (MZSP 1339): 33, dorsal view, 34, lateral view, 35, ventral view. Scale $1 \mathrm{~mm}$. 


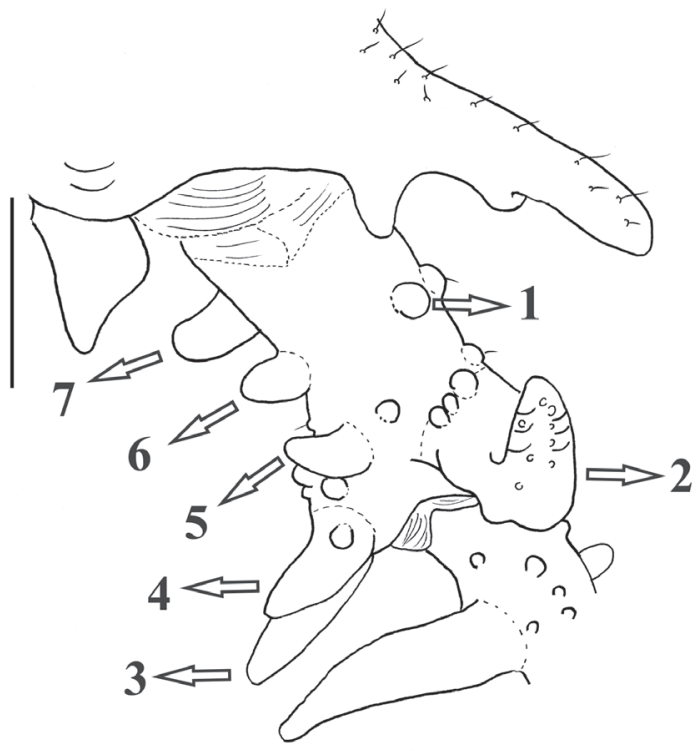

Fig. 36. Apophyses on male trochanter IV of Neopachylus mamillosus (SMF 1095): 1, median prodorsal; 2, apical prodorsal; 3, apical retrolateral; 4, apical retrodorsal; 5, subapical retrodorsal; 6, median retrolateral; 7, basal retrolateral. Scale $1 \mathrm{~mm}$.

a pair of robust, rounded paramedian tubercles, and 15 smaller tubercles uniformly distributed on each side. Posterior margin of dorsal scutum with one row of 15 rounded tubercles, two paramedian enlarged. Free tergites: all free tergites with a row of small rounded tubercles, the paramedian enlarged; I with 17 tubercles; II with 15 tubercles; III with 14 tubercles. Anal operculum with 14 small rounded scattered tubercles.

Legs (Figs 1; 15-17; 37): Coxa IV with prolateral apical bifid apophysis, dorsal stem longer than the ventral stem. Trochanter IV with two prodorsal apophyses, one apical robust and frontwards directed, with a subapical rounded tubercle, one median small and rounded apophysis; two retrodorsal apophyses, one apical conical, one median rounded; three retrolateral apophyses, one spiniform apical, backwards directed, one small conical median, one conical basal. Femur IV straight with a large spiniform retrolateral basal apophysis, four robust spiniform retrolateral median apophyses, two spiniform and two rounded; ventrally with one small rounded subbasal apophysis and one row of three rounded apophyses. Patella IV with one small prolateral apical apophysis. Tibia IV with two ventral rows of small conical apophyses. Tarsal counts: 6/9/7/7.

Penis (Figs 44-46). Ventral plate: distal and lateral margins concave; venter densely covered by simple microsetae on distal half, sparse setae on anterior half; three pairs of straight macrosetae $\mathrm{C} 1-\mathrm{C} 3$ aligned on latero-distal border of VP, C1-C2 subequal, inserted more closely to each other, $\mathrm{C} 3$ much shorter; macroseta D1 much reduced, lateral, midway between $A$ and $C$; three pairs of subequal latero-basal straight macrosetae A1A3 pointing proximally, close to each other in a triangle, median a little more ventrally placed. Stylus: stem long, straight, with subdistal filaments on lateral and ventral regions, frontwards directed, with swollen and smooth apex. Ventral process: almost parallel to stylus, thin, with apex curved downwards and serrate.

Coloration (in ethanol): Dorsal scutum, ocularium, coxa and tibia of legs IV, apophysis, tubercles, free tergites and anal operculum dark brown. Legs I, II, III and tarsus IV light brown. Chelicerae and venter light brown, dark brown reticulated. Pedipalps, scutal margins and scutal grooves, spots surrounding ocularium and frontal hump yellow.

Female (MZSP 30815). Measurements: SL 4.70; SMW 4.30; femur I 1.55; femur II 3.25; femur III 2.70; femur IV $3.65 \mathrm{~mm}$. Dorsum (Fig. 62): Prosoma with five small scattered tubercles; median rounded and robust tubercles of areas III/IV are smaller than in males.

Legs IV (Fig. 62): coxa shorter than in males, with a small prolateral apical pointed apophysis; trochanter, femur, patella and tibia unarmed, only covered by small rounded setiferous tubercles. Tarsal counts: 6 / 8/ 7 / 7 .

Geographical distribution (Fig. 71): Restrict to the coast of Southernmost Brazilian States (Santa Catarina and Rio Grande do Sul).

Intraspecific variation: Males with $1-3$ ripples on paramedian tubercles of areas III and IV. Males ( $\mathrm{n}=21)$ : SL 4.25-5.95; SMW 4.40-6.45; femur I 1.80-2.95; femur II 3.50-5.25; femur III 2.75-4.25; femur IV 3.60-7.00. Tarsal counts: 6/6-11/7/7; Females ( $n=11)$ : SL 4.50-5.70; SMW 4.25-4.70; femur I 1.50-2.50; femur II 2.30-3.75; femur III 2.50-3.55; femur IV 2.65-4.75. Tarsal counts: 6/7-9/7/7.

Material examined. BRAZIL, Rio Grande do Sul: Maquiné (FEPAGRO), 29³9'S, 50¹2'W, 18-27.I.2002, Equipe Biota col., ô (IBSP 4534); idem, ㅇ (IBSP 4329); idem, ô (MZSP 30812); idem (MZSP 30813); idem, $\widehat{\partial}$ (MZSP 30814); idem, $\circ$ (MZSP 28556); idem, $\hat{\jmath}$ (MZSP 30816); idem, $\hat{o}$, o (MZSP 30815); idem, ồ (MZSP 30817);

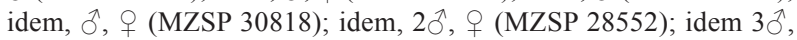
2 ㅇ (MZSP28555); idem, $\hat{o}$, ㅇ (MZSP 28572); idem, 2 $\hat{\jmath}$, 우 (MZSP 28567). Santa Catarina: Itajaí, $26^{\circ} 52^{\prime} 60^{\prime \prime} \mathrm{S}, 48^{\circ} 38^{\prime} 60^{\prime \prime} \mathrm{W}$, IX.1946, Gofferjé leg., + (MZSP 36243). Blumenau, "Parque Nacional Municipal Nascentes do Garcia", $27^{\circ} 01$ 'S, 4909'W, 21-28.I.2003, Equipe Biota col., $\widehat{o}$ (IBSP 5907).

\section{Neopachylus herteli Soares \& Soares, 1945}

(Figs $2 ; 9 ; 18-20 ; 38 ; 56 ; 57 ; 71$ )

Neopachylus herteli Soares \& Soares, 1945:372, figs 4, 4A [desc §̋]; 1947b:224 [key]; 1954:278 [cit, key]; PINTO-DA-Rocha \& CARON, 1989:1024 [cit]; KuRY, 2003:178 [cat]. (Type material: MHNCI

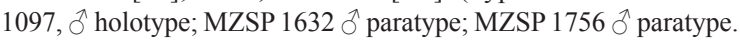
Examined. Type locality: Brazil, Paraná, Ponta Grossa, Vila Velha, $\left.25^{\circ} 13^{\prime} \mathrm{S}, 50^{\circ} 02^{\prime} \mathrm{W}, 830 \mathrm{~m}\right)$.

Diagnosis. Neopachylus herteli is similar to $N$. imaguirei and $N$. mamillosus in that it presents areas III and IV of dorsal scutum with a pair of oval rippled elevations (5-7 ripples each) and all free tergites with oval rippled elevations. It differs from them in that it presents one additional smaller median pair on area IV (Figs 2; 9). Trochanter IV with a prodorsal median apophysis curved, directed downwards, differs from $N$. imaguirei and $N$. mamillosus, which present it rounded (Fig. 38). 

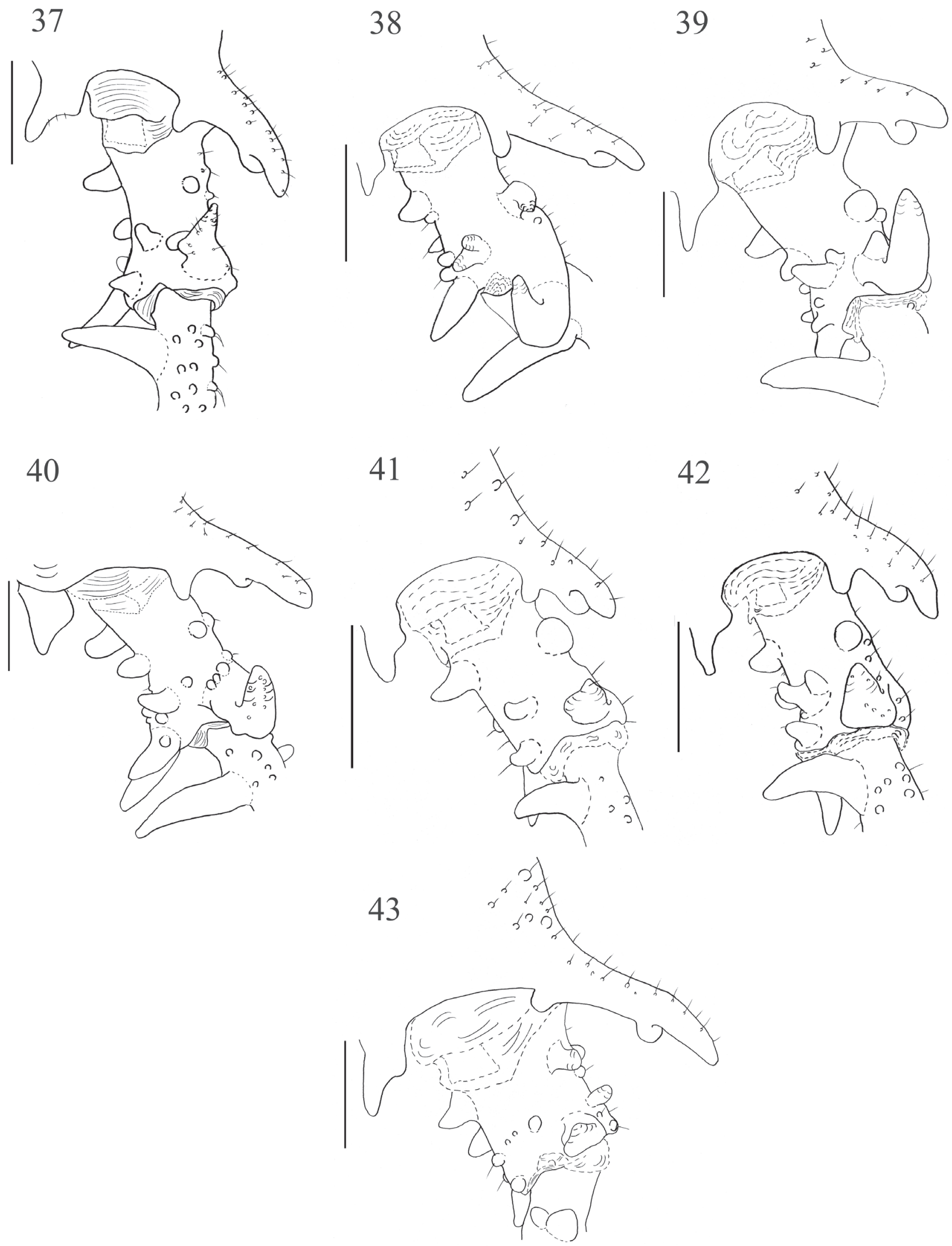

Figs 37-43. Trochanter IV of males of Neopachylus, dorsal view: 37, N. bellicosus (MZSP 30815); 38, N. herteli (MZSP 1632); 39, N. imaguirei (MZSP 1751); 40, N. mamillosus (SMF 1095); 41, N. nebulosus (MNRJ 42276); 42, N. serrinha (MZSP 1769); 43, N. taioensis (MZSP 1339). Scale 1mm. 

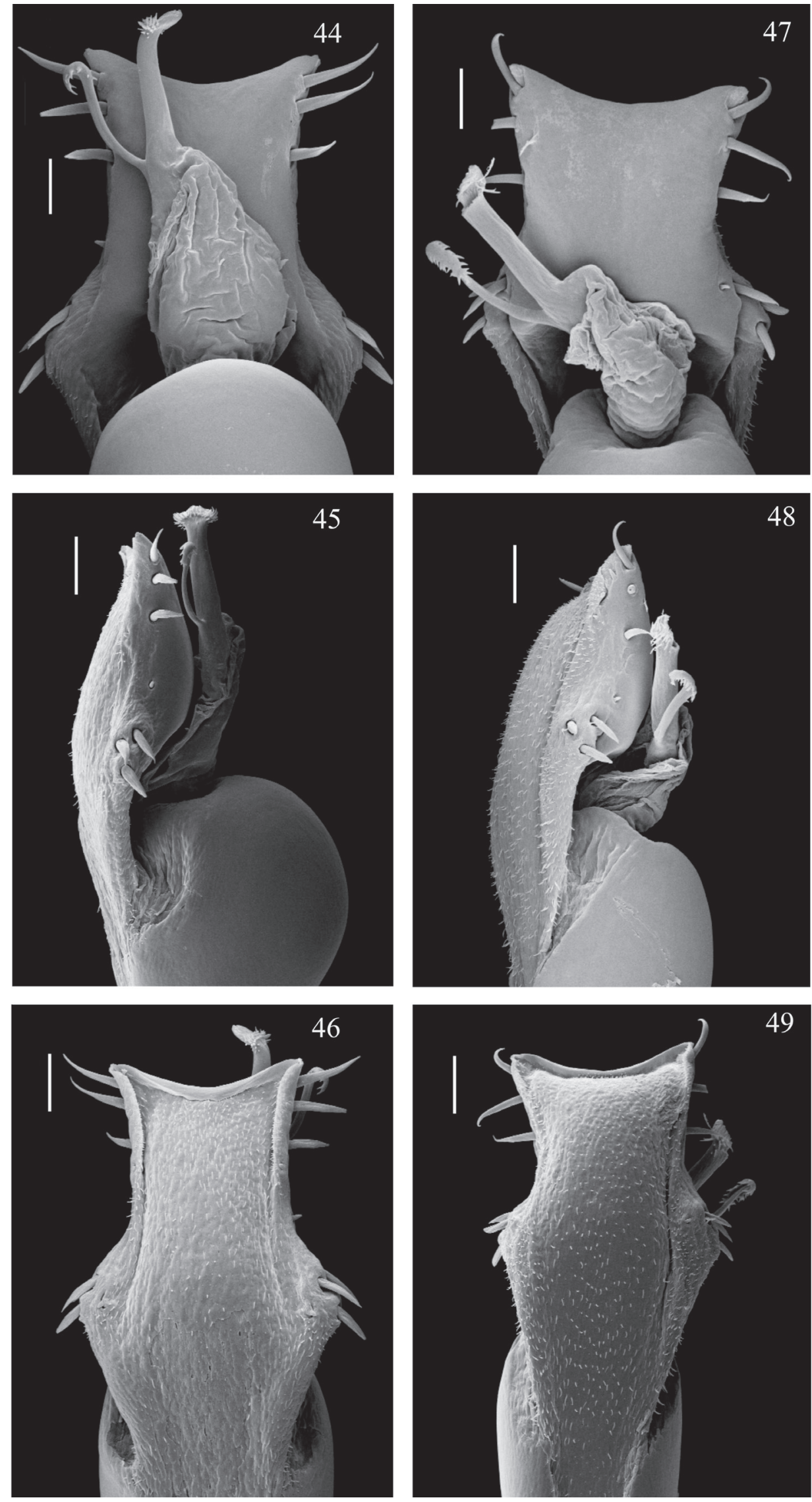

Figs 44-49. Distal part of penis of Neopachylus. Figs 44-46, N. bellicosus (MZSP 28567): 44, dorsal view, 45, lateral view, 46, ventral view. 47-49, N. imaguirei (MZSP 1256): 47, dorsal view, 48, lateral view, 49, ventral view. Scale $0.05 \mathrm{~mm}$. 

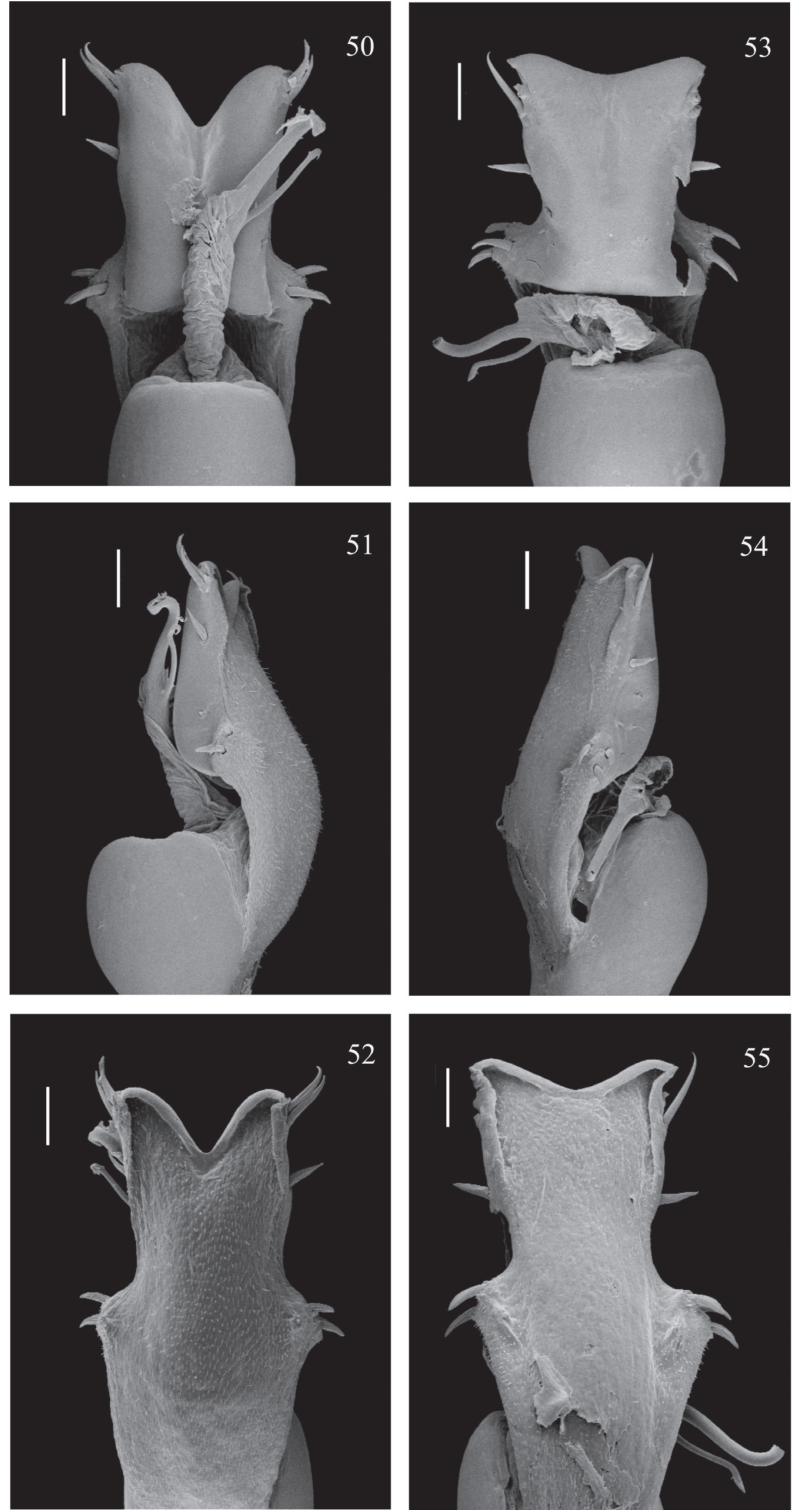

Figs 50-55. Distal part of penis of Neopachylus. Figs 50-52, N. nebulosus (MZSP 18167): 50, dorsal view, 51, lateral view, 52, ventral view. 53-55, N. serrinha (MZSP 1260): 53, dorsal view, 54, lateral view, 55, ventral view. Scale $0.05 \mathrm{~mm}$. 
Male (Paratype MZSP 1632). Measurements: SL 4.55; SMW 4.05; femur I 1.95; femur II 2.90; femur III 2.40; femur IV 2.50; HOA: 0.60. Dorsum (Figs 2; 9): Ocularium with a single median long apophysis, slightly directed frontwards with six small tubercles on base. Prosoma with six small scattered tubercles. Lateral margins of dorsal scutum with 15-17 rounded tubercles, beginning at the anterior grove of area I and reaching posterior groove of area IV. Area I with a pair of slightly enlarged paramedian tubercles and 3-4 smaller tubercles each side. Area II with a pair of slightly enlarged paramedian tubercles and 10 smaller tubercles scattered. Area III with a pair of oval rippled elevations, with five ripples each, and 10 small tubercles uniformly distributed. Area IV with two pairs of oval rippled elevations, one with seven ripples and one smaller, with five ripples each and five small tubercles on each side. Posterior margin of dorsal scutum with one row of 10 small oval rippled elevations, with 4-5 ripples each, and seven small rounded tubercles. Free tergites: I with 10 small oval rippled elevations, with 3-4 ripples each, and five small rounded tubercles; II with eight small oval rippled elevations, with 3-4 ripples each, and seven small rounded tubercles; III with eight small oval rippled elevations, with three ripples each, and six small rounded tubercles. Anal operculum with 22 small rounded tubercles.

Legs (Figs 2; 18-20; 38): coxa IV with prolateral apical apophysis bifid, dorsal stem longer than ventral stem. Trochanter IV with two prodorsal apophyses, one robust apical directed retrolaterally, one curved median directed downwards; two retrodorsal subapical apophyses geminate at base; five retrolateral apophyses, one large spiniform apical slightly directed backwards, one median conical, two small subbasal rounded and one basal conical, with a small rounded tubercle on its base. Femur IV curved, with one large, spiniform retrolateral basal apophysis, slightly directed backwards; one row of eight conical prolateral apophysis, median enlarged; ventrally with one row of six conical apophysis, from median to apical region, smaller than prolateral apophysis and one conical ventrobasal apophysis. Patella IV with a small spiniform prolateral apical apophysis. Tibia III with six small retrolateral conical apophyses. Tibia IV with prolateral and retrolateral rows of small conical setiferous apophyses in all extension. Tarsal counts: 6/6/6/6.

Penis (Figs 56; 57): Ventral plate. Distal and lateral margins concave; venter densely covered by simple microsetae; macrosetae $\mathrm{C} 2$ a little longer than the others; macrosetae D1 much reduced; three pairs A1-A3 of basal straight macrosetae, similar in size, in triangle, A2 more dorsally placed. Stylus. Stem long, straight, with subdistal filaments directed upwards on lateral and ventral region, swollen and smooth apex. Ventral process. Long, almost parallel to stylus, thin, with apex curved downwards and serrate.

Coloration (in ethanol): discolored, dorsal scutum yellow, rippled elevations light brown.

Female unknown.
Geographical distribution (Fig. 71): it is known only from type locality.

Intraspecific variation. Males ( $\mathrm{n}=3$ ): SL 4.35-4.55; SMW 3.85-4.05; femur I 1.35-1.95; femur II 2.70-2.90; femur III 2.00-2.40; femur IV 2.30-2.50. Tarsal counts: $6 / 6 / 6-8 / 6$

Material examined. Only the type material.

Neopachylus imaguirei Soares \& Soares, 1947

(Figs $3 ; 10 ; 21-23 ; 39 ; 47-49 ; 63 ; 71$ )

Neopachylus imaguirei SoAres \& Soares, 1947a: 80, fig. 13 [desc ô]; 1947b: 221, 224, fig. 8 [desc 9 , key]; 1954: 279 [cit]; KuRY, 2003: 178 [cat]. (Type material: MZSP 36142 ô holotype; MZSP 1751, 2 2 $\widehat{\partial}$ paratypes. Examined. Type locality: Brazil, Paraná, Piraquara Florestal).

Diagnosis. Similar to Neopachylus herteli e $N$. mamillosus in that it presents areas III and IV, posterior margin of dorsal scutum and free tergites with oval rippled elevations and femur IV strongly curved. It differs from $N$. herteli in that it presents tubercles scattered on areas I-II (almost in a median line in $N$. herteli) (Fig. 3) and from $N$. mamillosus in that it has the prolateral apical apophysis of coxa IV with dorsal stem almost the same size as the ventral stem (Fig. 21) and lateral margins of dorsal scutum with one row of rounded tubercles of the same size, beginning at the anterior groove of area I and reaching the posterior margin of dorsal scutum (Figs 3; 10).

Male (Paratype MZSP 1751). Measurements: SL 4.90; SMW 4.65; femur I 1.65; femur II 2.50; femur III 2.25; femur IV 2.70; HOA: 0.25. Dorsum (Figs 3; 10): Ocularium with a single median short apophysis slightly directed frontwards with six small setiferous tubercles on base. Prosoma with eight small scattered tubercles. Lateral margins of dorsal scutum with 22-20 rounded tubercles, beginning at anterior groove of area I and reaching the posterior margin of dorsal scutum. Area I with a pair of slightly enlarged paramedian tubercles, 6-7 small tubercles uniformly distributed on each side. Area II with a pair of slightly enlarged paramedian tubercles, 21 small tubercles uniformly distributed. Area III with a pair of oval rippled elevations, with six ripples each elevation and 25 small rounded tubercles uniformly distributed. Area IV with a pair of oval rippled elevations, with 7-8 ripples on each elevation, 11-15 small rounded tubercles on each side, uniformly distributed. Posterior margin of dorsal scutum with two pairs of oval rippled elevations on each side, with 3-8 ripples on each elevation, and row of 15 small rounded tubercles. Free tergites: I with a small oval rippled elevation (2-3 ripples by elevation) on each side, and a row of small rounded tubercles; II with one row of 14 tubercles; III with one row of nine tubercles. Anal operculum with 20 small rounded tubercles.

Legs (Figs 3; 21-23; 39): coxa IV with prolateral apical apophysis bifid, dorsal stem slightly longer than 
Taxonomic review of the Neotropical genus Neopachylus...

113
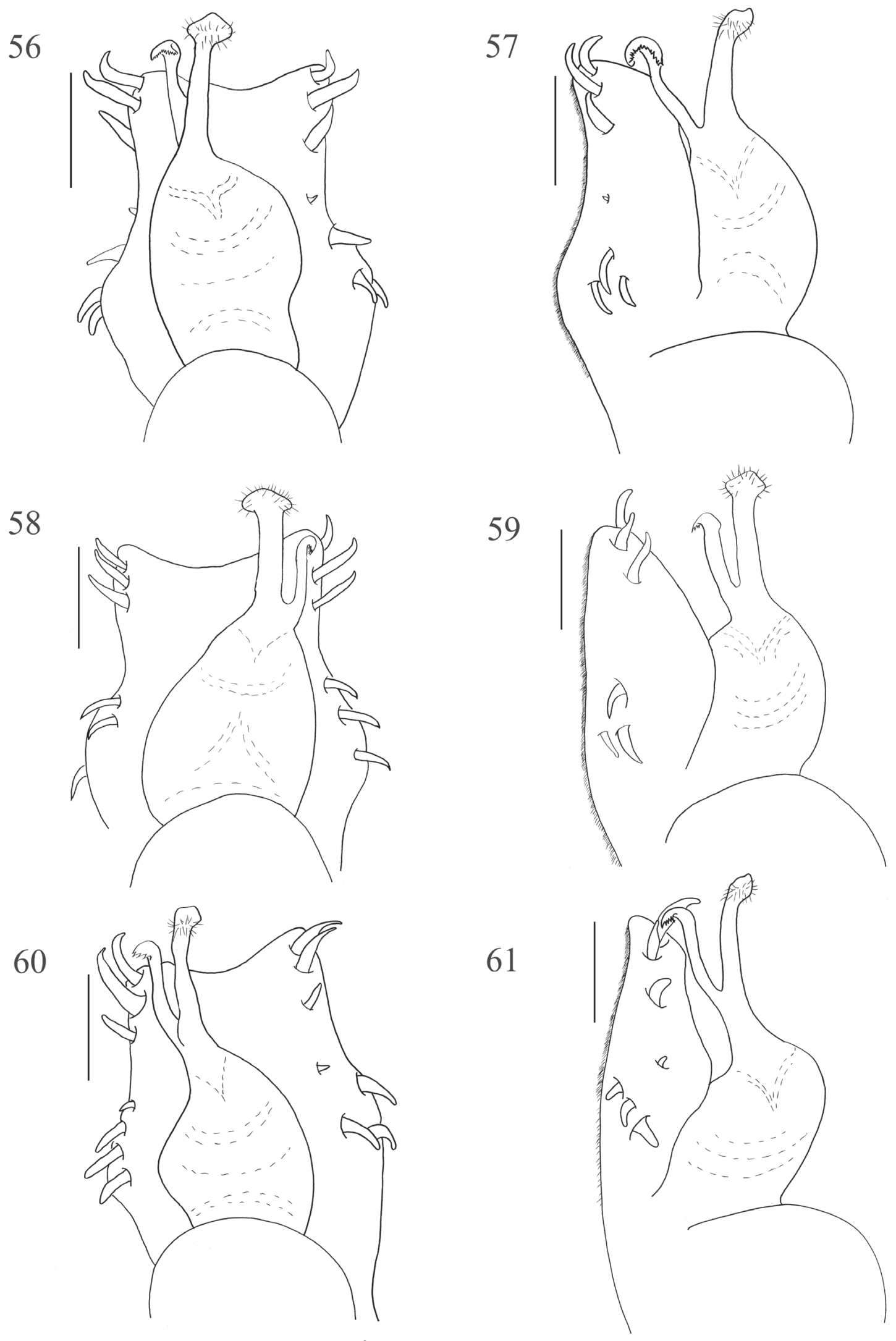

Figs 56-61. Distal part of penis of Neopachylus. Figs 56, 57, N. herteli (MZSP 1632): 56, dorsal view, 57, lateral view. 58, 59, N. mamillosus (SMF 1095): 58, dorsal view, 59, lateral view. 60, 61, N. taioensis (MZSP 1339): 60, dorsal view, 61, lateral view. Scale $0.1 \mathrm{~mm}$.

Iheringia, Série Zoologia, Porto Alegre, 105(1):101-121, 31 de março de 2015 
ventral stem. Trochanter IV with two prodorsal apophyses, one robust apical curved frontwards, with two small rounded tubercles on base, one median rounded; three retrodorsal apophyses, one small apical conical with a small tubercle anteriorly, two subapical conical, geminate at base; three retrolateral apophyses, one apical larger and pointed, backwards directed, one median and one basal conical. Femur IV strongly curved with one large, spiniform retrolateral basal apophysis with apex directed backwards; one pointed retrolateral subapical apophysis; five conical prolateral median apophyses, three small ventrobasal tubercles. Patella IV with one small prolateral apical apophysis. Tibia III with one row of six small spiniform retrolateral apophyses. Tibia IV with prolateral and retrolateral rows of small conical apophyses. Tarsal counts: 6/8/7/6.

Penis (Figs 47-49): Ventral plate. Distal and lateral margins concave; ventrally densely covered by simple microsetae; three pairs $\mathrm{C} 1-\mathrm{C} 3$ of latero-distal straight macrosetae similar in size, $\mathrm{C} 1$ and $\mathrm{C} 2$ closest to each other; macrosetae D1 much reduced, inserted between A and C, much closer to A cluster; macrosetae A1-A3 straight, clustered in a triangle, similar in size, A2 more ventral. Stylus. Stem long, straight, with subdistal filaments directed upwards, apex damaged. Ventral process. Long, almost parallel to stylus, thin, with apex curved downwards and serrate.

Coloration (in ethanol): discolored, yellow with elevations light brown.

Female (Paratype MZSP 1751). Measurements: SL 4.50; SMW 3.95; femur I 1.65; femur II 2.50; femur III 2.25; femur IV $2.70 \mathrm{~mm}$. Dorsum (Fig. 63): four small scattered tubercles on prosoma; areas I and II covered by small rounded tubercles, uniformly distributed, with the median pair enlarged. Armature of posterior margin, areas III and IV, not rippled as in male, represented by one pair of large rounded tubercles, with small tubercles uniformly distributed.

Leg IV (Fig. 63): coxa shorter than in males, one small prolateral apical pointed apophysis; trochanter, femur, patella and tibia unarmed, only covered by small rounded setiferous tubercles. Tarsal counts: 6/8/7/6.

Geographical distribution (Fig. 71): It is known from highlands in the state of Paraná.

Intraspecific variation. Males $(n=3)$ : SL 4.80-5.25; SMW 4.40-4.75; femur I 1.65-2.10; femur II 2.50-3.25; femur III 2.25-2.80; femur IV 2.70-3.00. Tarsal counts: 6/8-9/7-8/6. Females (n=5): SL 4.00-4.75; SMW 3.503.95; femur I 1.50-1.70; femur II 2.50-2.65; femur III 2.00-2.25; femur IV 2.70-3.20. Tarsal counts: 6/8/7-8/6.

Material examined. BRAZIL, Paraná: Curitiba, $25^{\circ} 25^{\prime} 00^{\prime}$ 'S, 49¹5'00”'W, XI. 1949, Hanny Zimmermann leg., ô, q (MNRJ 08995).

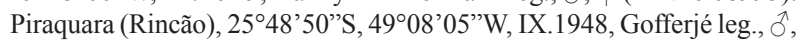
† (HS 0029); idem IV.1948, Gofferjé leg., ô, 2 q (MZSP 36248); idem,

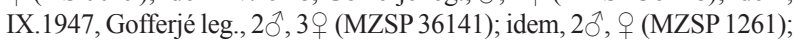
idem, IV.1950, ô (MHNCI 6268); Piraquara (Banhado), 2518’12”S, $50^{\circ} 32^{\prime} 34^{\prime \prime} W, 13 . I .1991$, R. Pinto-da-Rocha \& R. S. Bernils col., 4ð’, 2 ㅇ
(MHNCI 6839); Piraquara (Florestal), 2526’60”'S, 50³4'60”W, I.1946, Hatschbach col., 2犬̂, 2 + (MZSP 1750); idem, VII.1945, Gofferjé col.,

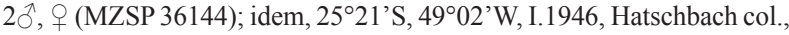
20, 2 ( (MZSP 988); São José dos Pinhais, $25^{\circ} 31^{\prime}$ 'S, $49^{\circ} 13^{\prime} \mathrm{W}$, I. 1950, Gofferjé leg., 4ð, 3 + (HEMS 0044); idem, Ir. C. Canatta leg., o (HEMS 0922); idem, VI.1944, Canatta leg., ㅇ (MZSP 1752); Km 77, estrada para Joinville, 26.I.1955, Pe. Moure \& R. Lange leg., 5ð, q (MHNCI

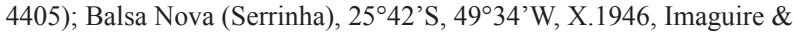

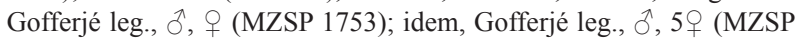
36291); idem, V.1948, 8 (MZSP 36304); idem, I.1948, 3 , q (MZSP 1256). Engenheiro Bley, $25^{\circ} 37^{\prime} \mathrm{S}, 49^{\circ} 45^{\prime} \mathrm{W}, \mathrm{V} .1945$, R. Lange leg., ${ }^{\lambda}$ (MHNCI 3346); idem, + (MHNCI 3347).

\section{Neopachylus mamillosus Roewer, 1915}

(Figs $4 ; 11 ; 24-26 ; 36 ; 40 ; 58 ; 59 ; 67 ; 68 ; 71$ )

Neopachylus mamillosus Roewer, 1915:99, fig. 54 [desc §̋]; 1923:415, fig. 516 a/b [rdesc]; Mello-Leitão, 1923:119 [cit]; 1932:193, fig. 107 [redesc/key]; 1933:135 [cit]; B. SoAres, $1945 \mathrm{~b}: 380$ [cit]; SoAres \& SOARES, 1947b:224 [key]; 1954:279 [cit]; ACOSTA, 1996:219 [cit]; KurY, 2003:178 [cat]. (Type material: SMF RI 1095, ô (holotype. Examined. Type locality: Brazil, Paraná, Tijuco Preto, railroad to Rio Negro, 24³7'S, 4958’ W).

Diagnosis. Similar to Neopachylus herteli and N. mamillosus in that it presents areas III and IV and posterior margin of dorsal scutum with oval rippled elevations and the femur IV strongly curved. It can be distinguished by tubercles of lateral margins of dorsal scutum beginning at the anterior groove of area II with tubercles enlarged near areas II and III and posterior margin of dorsal scutum with six oval rippled elevations ( $2-8$ ripples by elevation), three on each side (Figs 4; 11).

Male (Holotype SMF 1095). Measurements: SL 4.65; SMW 4.80; femur I 2.20; femur II 3.40; femur III 2.75; femur IV 3.00. Dorsum (Figs 4; 11): ocularium with a single median apophysis (damaged) with six small tubercles on base. Prosoma with six small scattered tubercles. Lateral margins of dorsal scutum with 15-13 rounded tubercles, beginning at the anterior groove of area II and reaching the posterior groove of area IV, enlarged at area II/III. Area I with a pair of slightly enlarged paramedian tubercles and five small scattered tubercles on each side. Area II with a pair of slightly enlarged paramedian tubercles and 14 small tubercles uniformly distributed. Area III with a pair of robust oval rippled elevations, with six ripples each, and 27 small rounded tubercles uniformly distributed. Area IV with a pair of robust oval rippled elevations, with 7-9 ripples, and 9-12 small rounded tubercles uniformly distributed on each side. Posterior margin of dorsal scutum with 3-4 oval rippled elevations on each side (with 3-8 ripples each one), and a row of 13 small rounded tubercles. Free tergites: I with two small median oval rippled elevations (with 2-3 ripples each), on each side of tergite, and a row of 15 small rounded tubercles; II with one row of 13 small rounded tubercles; III with one row of eight small rounded tubercles. Anal operculum with 15 small rounded tubercles.

Legs (Figs 4; 24-26; 36; 40; 67; 68): coxa IV with prolateral apical apophysis bifid, dorsal stem over twice 
62

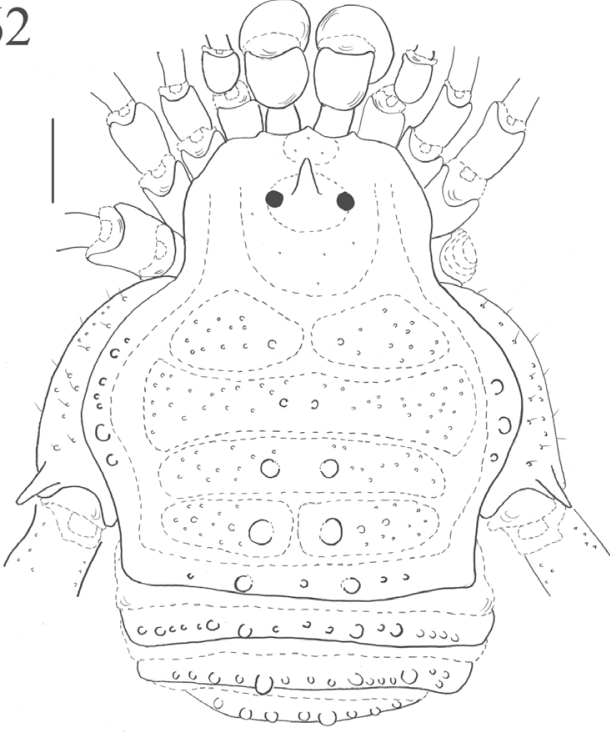

64

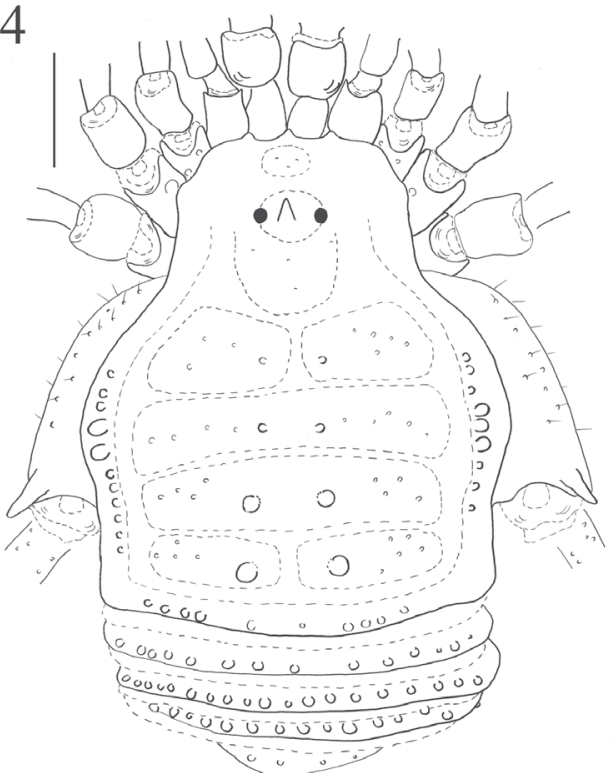

63

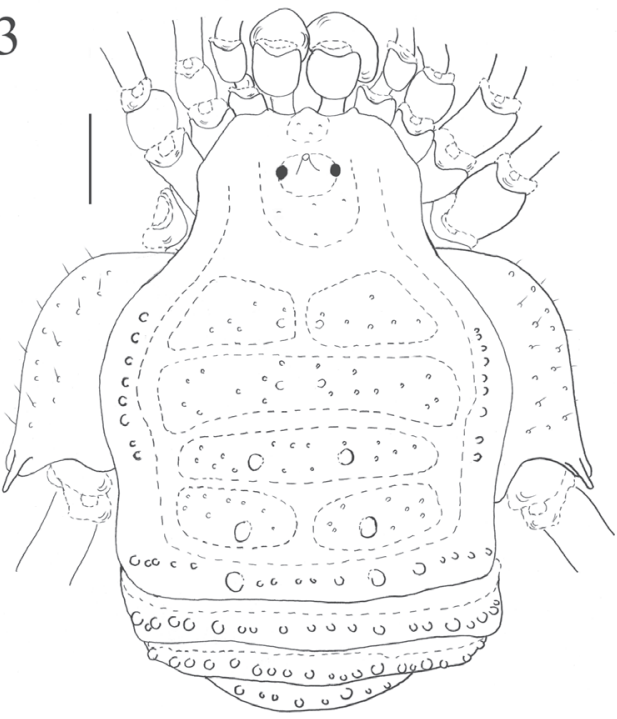

65

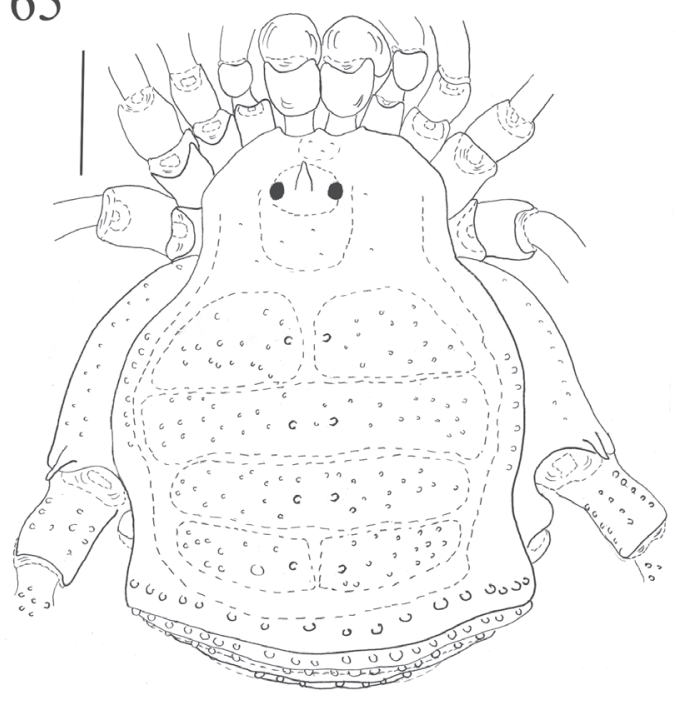

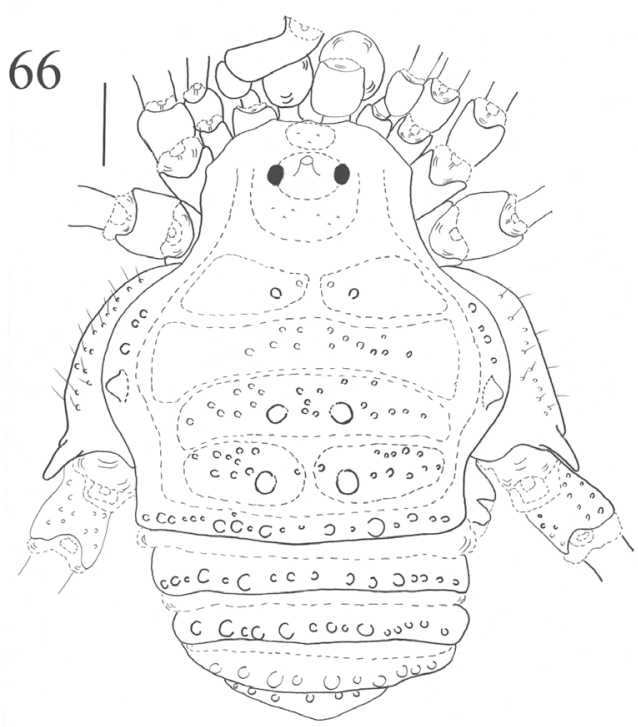

Figs 62-66. Habitus, dorsal view of females of Neopachylus: 62, N. bellicosus (MZSP 30815); 63, N. imaguirei (MZSP 1751); 64, N. nebulosus (MNRJ 42276); 65, N. serrinha (MZSP 1265); 66, N. taioensis (MZSP 1339). Scale $1 \mathrm{~mm}$. 
67

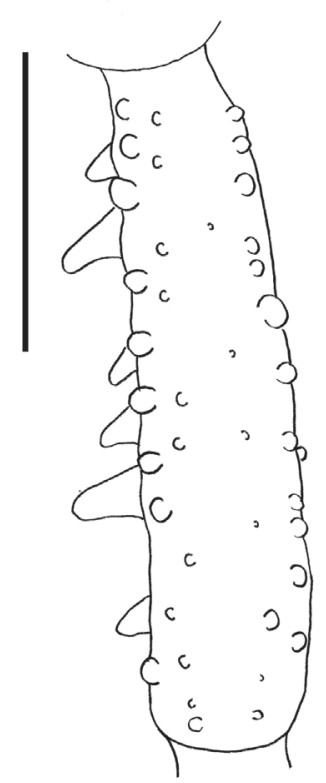

68

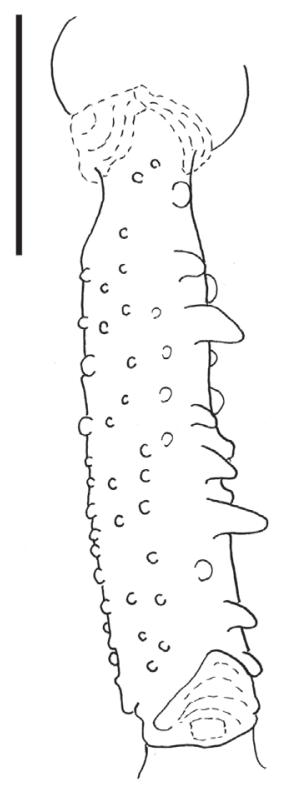

69

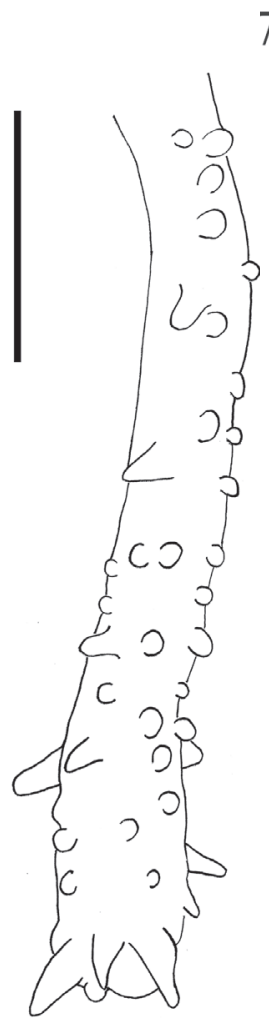

70

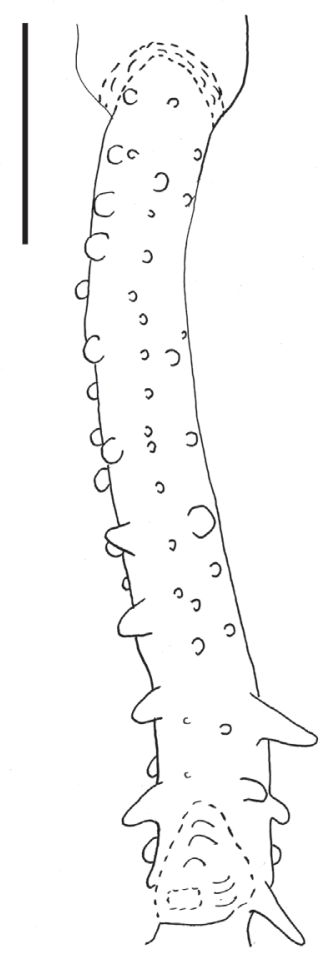

Figs 67-70. 67, 68, Tibia III of males of N. mamillosus (SMF 1095): 67, dorsal view, 68, ventral view ( $N$. herteli and $N$. imaguirei are similar to this species). 69, 70, Female femur IV of $N$. taioensis (MZSP 1339): 69, dorsal view, 70, ventral view. Scale: $1 \mathrm{~mm}$.

as long as ventral stem. Trochanter IV with two prodorsal apophyses, one small median rounded, one robust apical curved frontwards, with eight small tubercles on its apex and three tubercles on its base; two small rounded prolateral apophyses; two retrodorsal apophyses, one spiniform apical with three small rounded tubercles on its base, one subapical single and conical with one small rounded tubercle on its base; three retrolateral spiniform apophyses, one apical, one median (smaller), and one basal. Femur IV strongly curved, with one large spiniform retrolateral basal apophysis, slightly directed backwards, one row of three rounded prolateral median apophyses close to each other, one small prolateral apical apophysis; three retrolateral spiniform apophyses, one large, subapical directed backwards, one median, small with three small tubercles on its base, and one apical directed backwards, with small rounded tubercle on its base. Ventrally with two subbasal apophyses: one conical and other rounded, and three small basal tubercles. Patella IV with three small apophyses (prolateral, ventral and retrolateral). Tibia III with six small spiniform retrolateral apophyses, from base to apex. Tibia IV with prolateral and retrolateral rows of small conical apophyses in all extension. Tarsal counts: 6/9/7/6.

Penis (Figs 58; 59): Ventral plate. Distal and lateral margins concave; densely covered by simple microsetae on venter; macrosetae $\mathrm{C} 1-\mathrm{C} 3$ subequal, straight; macrosetae A1-A3 straight, subequal, A2 more ventral; macrosetae B and D indistinct. Stylus. Stem long, straight, with swollen apex with subdistal filaments directed upwards on lateral and ventral sides. Ventral process. Almost parallel to stylus, thin, with apex curved downwards and serrate.

Coloration (in ethanol): discolored, yellow, oval elevations light brown.

Female unknown.

Geographical distribution (Fig. 71): It is known only from type-locality.

Material examined. Only type material.

\section{Neopachylus nebulosus Mello-Leitão, 1936}

(Figs $5 ; 12 ; 27-29 ; 41 ; 50-52 ; 64 ; 71$ )

Nunduavius nebulosus Mello-Leitão, 1936:11, fig. 8 [desc đ̋]; B. SOARES, 1945a:193 [cit]; 1945b:380 [cit]; SOARES \& SOARES, 1954:280 [cit].

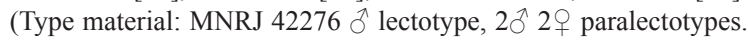
Examined. Type locality: Brazil, Paraná, Cachoeira).

Neopachylus nebulosus: KURY, 2003:178 [cat].

Huralvius incertus Mello-Leitão, 1935a:382, fig.12 [desc + ]; B. SoareS. 1945a:193 [cit]; 1945b:378 [cit]; SOARES \& SOARES, 1954:268 [cit]. (Type material: MNRJ 42440, + holotype examined. Type locality: Brazil, Paraná Cachoeirinha). Syn. nov.

Neopachylus incertus: KuRY, 2003:178 [cat].

Xuraloius incertus [misspelling]: MeLlo-Leitão, 1935b:102.

Diagnosis. Similar to Neopachylus bellicosus and $N$. taioensis in that it presents areas III and IV with a pair of large rounded and robust tubercles. It differs in that it presents short single median apophysis on ocularium, lateral margins of dorsal scutum and free tergites with one row of small rounded tubercles of the same size (Figs 5; 12). Male femur IV is similar to that of $N$. bellicosus, but differ in that it presents three retrolateral median pointed apophysis (basal smaller), slightly directed backwards 


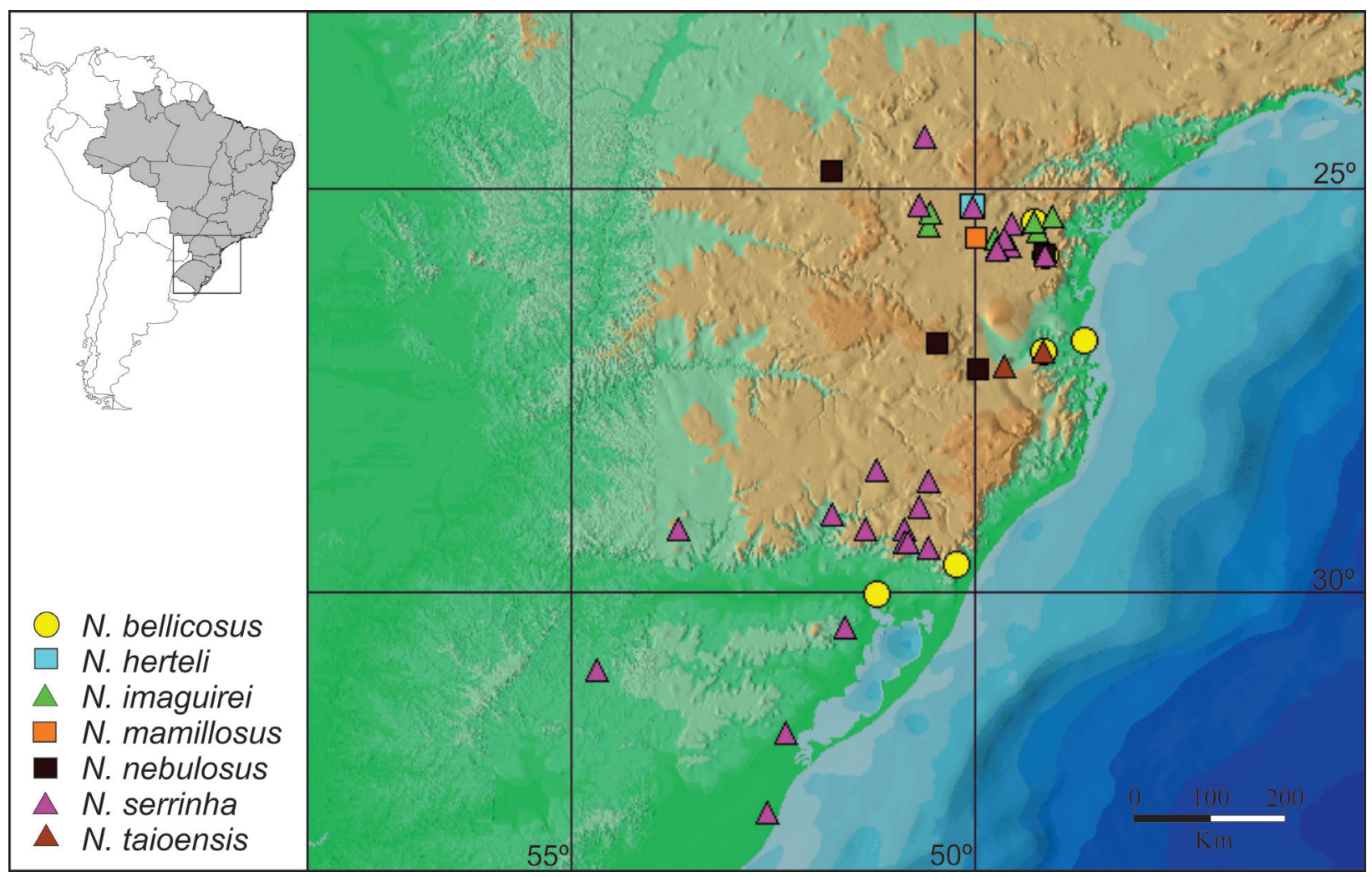

Fig. 71. Records of geographical distribution of Neopachylus in southern Brazil.

(Figs 27-29), prolateral median rounded apophysis absent as in N. bellicosus.

Male (Lectotype MNRJ 42276). Measurements: SL 4.50; SMW 4.30; femur I 2.30; femur II 3.50; femur III 3.15; femur IV 5.75; HOA: 0.30. Dorsum (Figs 5; 12): With a single short apophysis slightly directed frontwards, with five small rounded tubercles. Prosoma with five small scattered tubercles. Lateral margins of dorsal scutum with one row of 9-13 small rounded tubercles, beginning on area II and reaching the posterior groove of area IV. Area I with one pair of slightly enlarged paramedian tubercles, and two smaller on each side. Area II with one pair of slightly enlarged paramedian tubercles, and four scattered small tubercles. Area III with a pair of robust rounded paramedian tubercles, and four scattered small tubercles. Area IV with a pair of robust rounded paramedian tubercles, and three small tubercles on each side. Posterior margin of dorsal scutum with one row of 12 rounded tubercles, five median enlarged. Free tergites with small rounded tubercles: I with one row of 14 tubercles; II with one row of 13 tubercles; III with one row of 13 tubercles. Anal operculum with 15 small rounded tubercles.

Legs (Figs 5; 27-29; 41): coxa IV with prolateral apical apophysis bifid, dorsal stem slightly longer than ventral stem. Trochanter IV with two prodorsal apophyses, one median rounded, one robust straight apical, with apex slightly directed frontwards; two retrodorsal conical apophyses (on apical and subapical region); three retrolateral apophysis, one basal conical, one median, smaller and rounded, and one apical larger, pointed and directed backwards. Femur IV with one large, pointed retrolateral basal apophysis slightly directed backwards; three pointed retrolateral median apophyses, the basalmost smaller and rounded, remaining larger and slightly directed backwards; one small prolateral apical apophysis, directed backwards. Patella IV with a small prolateral apical apophysis, three ventral small apophyses. Tibia IV with a prolateral and retrolateral row of small spiniform tubercles in all extension. Tarsal counts: 6/9/7/7.

Penis (Figs 50-52): Ventral plate. Distal and lateral margins concave (Figs 51 and 52 show a cleft due to damage during preparation); ventrally densely covered by simple microsetae; macrosetae $\mathrm{C} 1-\mathrm{C} 3$ straight, $\mathrm{C} 1-\mathrm{C} 2$ larger and much closer to each other; macrosetae A1A2 straight, subequal, A1 more ventral, macrosetae D1 much reduced, a little shifted to dorsal, closest to A cluster. Stylus. Stem long and straight, with swollen Apex, subdistal filaments on lateral and ventral, directed upwards. Ventral process. Almost parallel to stylus, thin, with apex curved downwards and serrate.

Coloration (in ethanol): discolored, yellow, with paramedian tubercles light brown.

Female (Paralectotype MNRJ 42276). Measurements: SL 4.60; SMW 4.20; femur I 2.00; femur II 3.00; femur III 2.50; femur IV 3.85. Dorsum (Fig. 64): carapace with four scattered tubercles; median rounded tubercles in areas of dorsal scutum smaller than in males, 
uniformly distributed; lateral margins of dorsal scutum tubercles are larger near area II.

Legs IV (Fig. 64): coxa shorter than in males, with a small pointed prolateral apical apophysis; trochanter, femur, patella and tibia only covered by small setiferous tubercles. Tarsal counts: 6/8/7/7.

Synonymic note: Neopachylus incertus was described based on a female and it is here synonymized with $N$. nebulosus due to morphological similarities (areas I-II of dorsal scutum with one pair of slightly enlarged paramedian tubercles; areas III-IV with a pair of robust rounded paramedian tubercles; posterior margin and free tergites with one row of small rounded tubercles) and couples were found in the same localities.

Geographical distribution (Fig. 71): recorded from interior of states of Paraná and Santa Catarina, Brazil.

Instraspecific variation. Males ( $\mathrm{n}=3$ ): SL 4.40-4.50; SMW 4.25-5.00; femur I 2.30-2.75; femur II 3.50-4.25; femur III 3.15-3.55; femur IV 5.75-6.50. Tarsal counts: 6/9-10/7/7. Females: (n=7): SL 3.75-5.55 ; SMW 3.005.00; femur I 1.50-2.50; femur II 2.50-3.75; femur III 2.15-3.55; femur IV 3.25-4.75. Tarsal counts: 6/8-9/7/7. Females may present trochanter IV with small apical prodorsal conical apophysis, femur IV with small apophysis basal retrolateral conical, three small retrolateral spiniform apophyses.

Material examined. BRAZIL, Paraná: Curitiba, $25^{\circ} 25^{\prime} \mathrm{S}$,

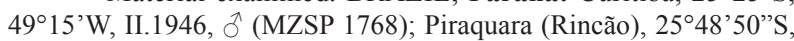

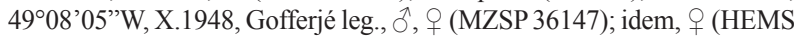
0027); Serra da Prata, 2446'60"S, 51 $04^{\circ} 60^{\prime \prime} \mathrm{W}, \mathrm{X} .1947$, Gengnagel leg., (HEMS 0213). Santa Catarina: Pouso Redondo (Serra Geral), $27^{\circ} 15^{\prime}$ S, $49^{\circ} 57^{\prime}$ W, 10. III.1999, Pinto-da-Rocha, Kury \& Giupponi leg., 5 ㅇ (MNRJ 5985); idem, ㅇ (MZSP 18182); idem, $\hat{O}, 3$ 우 (MZSP 18177); Santa Cecília (road BR-116), 2655’60”S, 50²7’00”W, 11.III.1999, A. Kury, R. Pinto-da-Rocha \& A. Giupponi, 4 3 , 3 (MZSP 18167); idem, đิ (MZSP 18166).

\section{Neopachylus serrinha Soares \& Soares, 1947}

(Figs $6 ; 13 ; 30-32 ; 42 ; 53-55 ; 65 ; 71$ )

Neopachylus serrinha SOARES \& SoARES, 1947b:222, 224 figs 9-10 [desc ô, key]; 1954: 279 [cit]; H. SoAREs, 1966a:93 fig. 6 [desc P]; 1966b:121 [cit]; TAVARES, 1980:156 [cit]; PINTO-DA-ROCHA \& CARON, 1989:1024 [cit]; KuRY, 2003 [cat]. (Type material: MHNCI 3627, $\delta$ holotype; MZSP 989, 20 paratype; MZSP 1769, ô paratype). Examined. Type locality: Brazil, Paraná, Balsa Nova, Serrinha, $25^{\circ} 43^{\prime} \mathrm{S}, 49^{\circ} 43^{\prime} \mathrm{W}$ ).

Gephyropachylus marginatus Mello-Leitão, 1931:14 [desc]; 1932:441 [cit]; B. SoARES, 1945b:384 [cit]. (Type material: MNRJ 1364, 4 우 syntypes. Examined. Type locality: Brazil, Rio Grande do Sul. Taquara: Caracol waterfall). Syn. nov.

Neopachylus marginatus: KURY, 2003:178 [cat].

Diagnosis. It is similar to Neopachylus herteli, $N$. imaguirei and $N$. mamillosus in that it presents areas III and IV of dorsal scutum with one pair of oval rippled elevations. The lateral margins of dorsal scutum with one row of rounded tubercles of same size from area I to IV and apophyses of trochanter IV make it very similar to $N$. imaguirei, it differs from them in that it has less ripples on elevations (2-4) of areas III and IV and posterior margin of dorsal scutum and free tergites with one row of small rounded tubercles of same size, without rippled elevations (Figs 6; 13).

Male (Paratype MZSP 1769). Measurements: SL 4.50; SMW 4.30; femur I 2.25; femur II 3.25; femur III 2.80; femur IV 4.00; HOA: 0.40. Dorsum (Figs 6; 13): ocularium with short single apophysis slightly directed frontwards, with eight small setiferous tubercles on base. Prosoma with five small scattered tubercles. Lateral margins of dorsal scutum with 14-15 small rounded tubercles, beginning at the anterior groove of area I and reaching the anterior groove of area IV. Area I with a pair of slightly enlarged paramedian tubercles and 8 tubercles on each side. Area II with a pair of slightly enlarged paramedian tubercles and 35 small rounded tubercles uniformly distributed. Area III with a pair of oval robust rippled elevations, with three ripples each, and 29 small rounded tubercles uniformly distributed. Area IV with a pair of oval robust rippled elevations, with 3-4 ripples each, and 12-13 small rounded tubercles uniformly distributed on each side. Posterior margin of dorsal scutum with one row of 14 small rounded tubercles. Free tergites with small rounded tubercles: I with one row of 19 tubercles; II with one row of 16 tubercles; III with one row of 13 tubercles. Anal operculum with 15 small rounded tubercles.

Legs (Figs 6; 30-32; 42): coxa IV with prolateral apical apophysis bifid, dorsal stem almost the same size as the ventral stem. Trochanter IV with two prodorsal apophyses, one median rounded, one apical robust with apex directed frontwards; two retrodorsal apophyses, one apical rounded and one subapical geminate at base; three retrolateral apophyses, one basal conical, one median conical, one large, spiniform apical directed backwards. Femur IV slightly curved, with a large spiniform retrolateral basal apophysis with apex slightly directed backwards; one row of five rounded prolateral apophyses from subbasal to median region; three retrolateral pointed apophyses, two median and one subapical larger and pointed; two small apical apophyses (prolateral and retrolateral). Patella IV with two small spiniform ventroapical apophyses. Tibia IV with prolateral and retrolateral rows of small conical apophyses from base to apex. Tarsal counts: 6/9/6/6-7.

Penis (Figs 53-55): Ventral plate. Distal and lateral margins concave; densely covered by simple microsetae, more sparse on median and basal regions; macrosetae $\mathrm{C} 1$ C3 (damaged) straight, $\mathrm{C} 1-\mathrm{C} 2$ longer and much closer to each other, pointing distal, $\mathrm{C} 3$ pointing lateral; macrosetae A1-A3 straight, subequal, A2 more ventral, macrosetae D1 much reduced, a little shifted to dorsal, closest to A cluster. Stylus. Stem long, straight (apex damaged). Ventral process. Almost parallel to stylus, thin, with apex curved downwards and serrate.

Coloration (in ethanol): dorsal scutum, ocularium, coxa-tibia of leg IV, apophyses, tubercles, free tergites and anal operculum dark brown. Legs I, II, III and tarsus 
IV light brown. Chelicerae and venter light brown, dark brown reticulated. Pedipalps, margins and grooves of dorsal scutum, spots surrounding ocularium and frontal hump, yellow.

Female (Paratype MZSP 1265). Measurements: SL 4.65; SMW 3.90; femur I 1.50; femur II 2.60; femur III 1.95; femur IV $2.80 \mathrm{~mm}$.

Dorsum (Fig. 65): with seven small scattered tubercles on prosoma; armature of dorsal scutum areas are small rounded tubercles, paramedian slightly larger than the others.

Legs IV (Fig. 65): with coxa shorter than in males, with a small prolateral apical pointed apophysis; trochanter, femur, patella and tibia only covered by setiferous tubercles. Tarsal counts: 6/8/5/5.

Synonymic note: $N$. marginatus was described based on female and is here synonymized under $N$. serrinha because of the great morphological similarity (areas I-IV of dorsal scutum with one pair of slightly enlarged paramedian tubercles; posterior margin and free tergites with one row of small rounded tubercles) in several lots from different localities.

Geographical distribution (Fig. 71): recorded in interior of Paraná and near Coast to interior of the state of Rio Grande do Sul.

Intraspecific variation. Males ( $\mathrm{n}=2$ ): SL 4.00-4.50; SMW 3.65-4.30; femur I 1.75-2.25; femur II 3.00-3.25; femur III 2.25-2.80; femur IV 3.30-4.00. Tarsal counts: 6/9/6-7/6-7; females ( $\mathrm{n}=5)$ : SL 3.75-4.65; SMW 3.353.90; femur I 1.50-2.00; femur II 2.00-3.25; femur III 1.552.60; femur IV 2.75-3.85. Tarsal counts: 6/6-9/5-7/5-7.

Material examined. BRAZIL, Paraná: Campo Largo (Rio

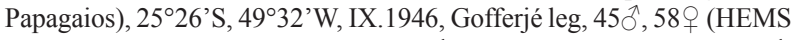
0908); idem, ㅇ (HEMS 0915); idem, $8 \hat{\jmath}, 8$ (HEMS 0032); idem, $15 \hat{\text {, }}$, 16 ㅇ (HEMS 0165); Ponta Grossa (Vila Velha), $25^{\circ} 13^{\prime} \mathrm{S}, 50^{\circ} 02^{\prime} \mathrm{W}$, 16.VII.1948, Rudini leg., 2ð, 2 9 (MNRJ 34952); idem, 8ภ, 5 ㅇ (MZSP 1265); idem, 20ㅅ․ 13 우 (MZSP 36298); Desvio Ribas, $25^{\circ} 11^{\prime} \mathrm{S}, 50^{\circ} 04^{\prime} \mathrm{W}$, 17.III.1947, K. Imaguire leg., 32ર̂, 21 우 (MZSP 36279); idem, 4^,

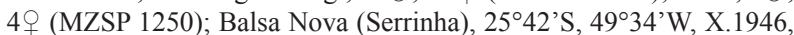
Imaguire \& Gofferjé leg., $2 \hat{\jmath}, 2$ (MZSP 1749); idem, 12へ, 99 (MZSP

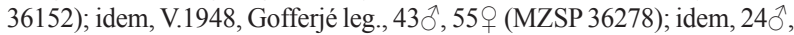
23 + (MZSP 36287); (Serra de São Luiz), 2536’S, 49³7’ W, 07.III.1999, R. Pinto-da-Rocha, A. Kury \& A. Giupponi col., 5 ㅇ (MNRJ 5984);

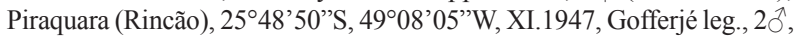
5 (MZSP 36236); idem, XI.1948, Gofferjé leg., 8̂ै, 2 ㅇ (MZSP 1260); Harmonia (Telêmaco Borba), 24²1'S, 50³7'W, VII.1951, Gofferjé leg., ${ }^{\lambda}, q$ (MHNCI 6267). Rio Grande do Sul: Ana Rech (Vila Oliva), $29^{\circ} 14^{\prime}$ 'S, 505' 'W, 18.II.1949, 50, ㅇ (HEMS 0077); idem, 14.IX.1976, M. L. Tavares leg., 7 (MCN 0193); São Francisco de Paula (Cazuza Ferreira), $28^{\circ} 56^{\prime} 60^{\prime \prime}$, 50 50 40 $00^{\prime \prime} \mathrm{W}, 23 . \mathrm{IV} .1974$, A. A. Lise leg., 2 ㅇ (MCN 0335); (Passo dos Bugres), 29²6'52”S, 50³5’02”W, 04.XI.1988, ð’, 우 (MCN 1370); idem, 6.XI.1998, A. Silva leg., \& (MCN 1375); Esmeralda (Estação Ecológica Aracuri), $28^{\circ} 03^{\prime}$ 'S, $51^{\circ} 12^{\prime}$ W, 27.IX.1979, C. J. Becker

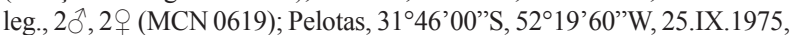
A. A. Lise col., $3 \hat{\gamma}, 3$ ( $(\mathrm{MCN}$ 0459); idem, ㅇ (MCN 0436); Canela, $29^{\circ} 22^{\prime} 00^{\prime \prime S}, 50^{\circ} 49^{\prime} 60^{\prime \prime} \mathrm{W}, 04 . \mathrm{I} .1975$, V. W. Thomé col., + (MCN 0176); idem, 25.II.1974, A. A. Lise col., $2{ }^{\jmath}$, ᄋ (MCN 0446); Dom Pedrito, 3058'60”S, 5440’00”W, 01.III.1976, C. J. Becker leg., + (MCN 0433); Rio Grande (Estação Ecológica do Taim), 32॰44’33”S, 52॰34'28”W, 15.X.1985, E. H. Buckup col., ㅇ (MCN 0870); idem, 01.VII.1986, A. Brescovit col., §ิ (MCN 0957); idem, 02.IX.1986, A. A. Lise col., ô, 2 (MCN 0940); idem, 12-18.XII.1986, A. A. Lise col., $2{ }^{\dagger}$ (MCN
0895); Julio de Castilhos, 29॰13'60"S, 5340'60"W, 12.X.1979, D.

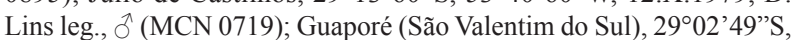
5145'54”'W, 16.X.1976, S. Scherer leg., ô (MCN 0431); Cambará do

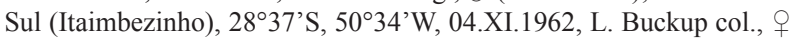
(MCN 0434); Farroupilha (Parque Santa Rita Garibaldi), 29¹3'60”S,

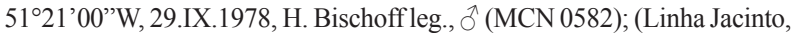
Sítio Ziero), 29¹3'60"S, 51²1'00”W, 08.XI.1983, T. de Lima col.,

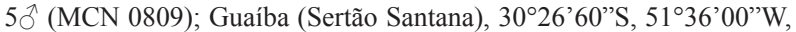

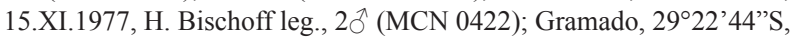
5052’26”'W, 15.I.1965, J. W. Thomé col., ô, o ( $(\mathrm{MCN} 0438)$.

\section{Neopachylus taioensis Soares, 1966}

(Figs $7 ; 14 ; 33-35 ; 43 ; 60 ; 61 ; 66 ; 69-71$ )

Neopachylus taioensis H. SOARES, 1966a:94, Figs 10-11 [desc ð̊]; KURY, 2003:178 [cat]. (Type material: MZSP $36167 \AA$ đ, 2 ㅇ paratypes. Examined. MZSP 1339 ô paratype. Holotype private collection Gofferjé lost. Type locality: Brazil, Santa Catarina, Taió: Rio do Sul).

Diagnosis. Similar to N. bellicosus and N. nebulosus in that it presents areas III and IV of dorsal scutum with a paramedian pair of rounded and robust tubercles. It differs in that it has lateral margins of dorsal scutum with one elevation near grove III (Fig. 7), trochanter IV with low apical prodorsal apophysis (smaller than other Neopachylus species) with apex directed frontwards (Fig. 43) and femur IV with two rounded dorsobasal apophyses geminate at base (exclusive of $N$. taioensis) (Fig. 33).

Male (paratype MZSP 1339). Measurements: SL 4.95; SMW 5.10; femur I 2.00; femur II 3.70; femur III 2.95; femur IV 3.75; HOA: $0.60 \mathrm{~mm}$. Dorsum (Figs 7; 14): ocularium with single long apophysis, slightly directed frontwards, with six small tubercles on base. Prosoma with 5 small scattered tubercles. Lateral margins of dorsal scutum with one elevation on each side, near groove III, with a large rounded tubercle on each elevation and one row of 7-9 small rounded tubercles, beginning at posterior groove of area I and reaching the anterior groove of area III. Area I with a pair of slightly enlarged paramedian tubercles and two small tubercles on each side; Area II with a pair of slightly enlarged paramedian tubercles and 12 small tubercles uniformly distributed; Area III with pair of paramedian rounded robust tubercles and 15 small tubercles uniformly distributed; Area IV with a pair of paramedian rounded robust tubercles and 3-6 small tubercles on each side. Posterior margin of dorsal scutum with one row of 13 rounded tubercles, median enlarged. Free tergites with small rounded tubercles: I with one row of 15 tubercles; II with one row of 12 tubercles; III with one row of nine tubercles. Anal operculum with 12 small rounded tubercles.

Legs (Figs 7; 33-35; 43): coxa IV with prolateral apical apophysis bifid, dorsal stem larger than ventral stem. Trochanter IV with two prodorsal apophyses, one median rounded, one large apical with apex directed frontwards, with two small rounded tubercles between them; one subapical prolateral rounded apophysis; five rounded retrodorsal apophyses, one apical, four subapical; three pointed retrolateral apophyses, one basal, one median, 
one apical (directed backwards). Femur IV straight, with two rounded dorsobasal apophyses geminate at base; two dorsomedian curved retrolaterally apophyses; three small rounded prolateral subbasal apophyses; one small spiniform prolateral apical apophysis, with apex slightly directed backwards; one pointed retrolateral subapical apophysis; four ventral apophyses, two rounded basal close to each other, one subbasal conical, one median large rounded curved retrolaterally. Patella IV with two spiniform ventroapical apophyses. Tibia IV with one prolateral and one retrolateral rows of small conical setiferous apophyses, in all extension. Tarsal counts: 6/9/7/7.

Penis (Figs 60; 61): Ventral plate. Distal and lateral margins concave; ventrally densely covered by simple microsetae, more sparse on basal region; macrosetae $\mathrm{C} 1$ C3 straight, C3 clearly smaller, C1-C2 longer and closer to each other; D1 much reduced, inserted between macrosetae A and C; macrosetae A1-A3 straight, clustered in triangle, A 3 a bit smaller, A2 more dorsally inserted. Stylus. Long stem, straight, with subdistal filaments directed upwards, swollen and smooth apex. Ventral process. Almost parallel to stylus, thin, with apex curved downwards and serrate.

Coloration (in ethanol): discolored, yellow, with apophysis tubercles light brown.

Female (Paratype MZSP 36167). Measurements: SL 5.20; SMW 4.75; femur I 2.00; femur II 3.75; femur IV $4.10 \mathrm{~mm}$. Dorsum (Fig. 66): six small scattered tubercles on prosoma; tubercles of areas III/IV of dorsal scutum are smaller than males, more conical than rounded.

Legs IV (Figs 66; 69; 70): coxa shorter than males, with a small pointed prolateral apical apophysis. Femur IV with four small spiniform apophyses on median dorsal region, three apical smaller, four prolateral and one retrolateral enlarged. Tibia IV with two ventral rows of small spiniform apophyses, from median to apical regions. Trochanter, femora I-III, patella and tibia only covered by setiferous tubercles. Tarsal counts: 6/9/7/7.

Geographical distribution (Fig. 71): It is known only from two localities east part of plateaeu in the Santa Catarina State.

Intraspecific variation. Males. $(\mathrm{n}=2)$ : SL 4.95-5.00; SMW 5.00-5.55; femur I 2.00-2.25; femur II 3.70-4.50; femur III 2.95-4.25; femur IV 3.75-4.10 mm. Tarsal counts: 6/ 8-9/ 7/ 7. Females $(n=4)$ : SL 4.75-5.25; SMW 4.35-4.75; femur I 2.00; femur II 3.50-3.75; femur III 2.80-3.00; femur IV 3.75-4.15 mm. Tarsal counts: 6/ 8-9/ 7/ 7.

Material examined. BRAZIL, Santa Catarina: Blumenau (Parque Nacional Municipal "Nascentes do Garcia", 2701'S, 49 $09^{\circ} \mathrm{W}$, 21-28.I.2003, Equipe Biota col., §̋ (IBSP 6002); idem, ㅇ (IBSP 5839); idem $q$ (IBSP 5925).

Acknowledgments. We are grateful to the following curators who loaned us material: Adriano B. Kury (Museu Nacional do Rio de Janeiro), Julio C. de Moura-Leite (Museu de História Natural Capão da Imbuia), Ricardo Ott (Museu de Ciências Naturais), and Peter Jäger (SMF - Senckenberg Museum). We thank John Ponting and Adriano B. Kury for the English review. This study was supported by CNPq (VM, RPR) and FAPESP (RPR, CB).

\section{REFERENCES}

Acosta, L. E. 1996. Die Typus-Exemplare der von Carl-Friedrich Roewer beschriebenen Pachylinae (Arachnida: Opiliones: Gonyleptidae). Senckenbergiana Biologica 76:209-225.

Acosta, L. E.; Pérez-González, A. \& Tourinho, A. L. 2007. Methods and techniques of study: Methods for taxonomic study. In: PinToDa-Rocha, R.; Machado, G. \& Giribet, G. eds. Harvestmen. The Biology of Opiliones. Massachusetts, Harvard University Press. 595p.

Bragagnolo, C. \& Pinto-Da-Rocha, R. 2012. Systematic review of Promitobates Roewer, 1913 and cladistic analysis of Mitobatinae Simon, 1879 (Arachnida, Opiliones, Gonyleptidae). Zootaxa 3308:148

Caetano, D. S. \& Machado, G. 2013. The ecological tale of Gonyleptidae (Arachnida, Opiliones) evolution: phylogeny of a Neotropical lineage of armoured harvestmen using ecological, behavioural and chemical characters. Cladistics 29:589-609.

Da Silva, M. B. \& Pinto-da-Rocha, R. 2010. Systematic review and cladistic analysis of the Hernandariinae (Opiliones: Gonyleptidae). Zoologia 27:577-642.

Hara, M. R.; Pinto-da-Rocha, R. \& Kury, A. B. 2012. Revision of Nanophareus, a mysterious harvestman genus from Chile, with descriptions of three new species (Opiliones: Laniatores: Gonyleptidae). Zootaxa 3579:37-66.

Hijmans, R. J.; Guarino, L.; Bussinik, C.; Mathur, P.; Cruz, M.; Barrentes, I. \& RoJAs, E. 2004. DIVA-GIS. Version 5.0. A geographic information system for the analysis of species distribution data. Available at $<$ http://www.diva-gis.org $>$. Accessed on December 2014.

KurY, A. B. 1995. A review of Huralvioides (Opiliones, Gonyleptidae, Pachylinae). Amazoniana 13:315-323.

. 2003. Annotated catalogue of the Laniatores of the New Word (Arachnida, Opiliones). Revista Ibérica de Aracnologia 1:5-337 (Volumen especial monográfico).

2013. Order Opiliones Sundevall, 1833. In: Zhang, Z.-Q. ed. Animal Biodiversity: An Outline of Higher-level Classification and Survey of Taxonomic Richness (Addenda 2013). Zootaxa 3703:27-33.

Kury, A. B. \& Villarreal, O. 2015. The prickly blade mapped: establishing homologies and a chaetotaxy for macrosetae of penis ventral plate in Gonyleptoidea (Arachnida, Opiliones, Laniatores). Zoological Journal of the Linnean Society (in press).

Mello-Leitão, C. F. 1923. Opiliões Laniatores do Brasil. Arquivos do Museu Nacional do Rio de Janeiro 24:107-197.

1926. Notas sobre Opiliones Laniatores sulamericanos. Revista do Museu Paulista 14:327-383. 1931. Arachnideos do Rio Grande do Sul. Boletim Biológico, N. serie 33:117-148

1932. Opiliões do Brasil. Revista do Museu Paulista 17:1-505. 1933. Novos Gonyléptidae do Brasil Meridional. Archivos da Escola Superior de Agricultura e Medicina Veterinária 10:133151.

1935a. A propósito de alguns opiliões novos. Memórias do Instituto Butantan 9:369-411.

1935b. Algumas notas sobre os Laniatores. Archivos do Museu Nacional, Rio de Janeiro 36:87-116.

1936. Notas sobre opiliões. Boletim do Museu Nacional do Rio de Janeiro 12:1-41.

1937. Notas sobre opiliões do Instituto Butantan. Memórias do Instituto Butantan 10:289-295.

1938. Considerações sobre os Phalangodoidea Soer. with descrição de novas formas. Annaes da Academia Brasileira de Sciencias 10:135-145.

Mendes, A. C. 2011. Phylogeny and taxonomic revision of the Heteropachylinae (Opiliones: Laniatores: Gonyleptidae). Zoological Journal of the Linnean Society 163:437-483.

Muñoz-Cuevas, A. 1973. Sur les caractères génériques de la familie des Gonyleptidae (Arachnida, Opiliones, Laniatores). Bulletin du Muséum National d'Histoire Naturelle (3) 87(113):225-234.

Pinto-Da-Rocha, R. 1997. Systematic review of the Family Stygnidae (Opiliones: Laniatores: Gonyleptoidea). Arquivos de Zoologia 33:163-342. 
2002. Systematic review and cladistic analysis of the Caelopyginae (Opiliones, Gonyleptidae). Arquivos de Zoologia 36:357-464.

Pinto-DA-Rocha, R. \& CARon, S. F. 1989. Catálogo do Material-tipo da coleção de Arachnida Rudolf Bruno Lange do Museu de História Natural "Capão da Imbuia", Curitiba, Paraná. Brasil. Revista Brasileira de Biologia 49:1021-1029.

Pinto-da-Rocha, R.; Bragagnolo, C.; Marques, F. P. L. M. \& Antunes $\mathrm{J}_{\mathrm{R}}, \mathrm{M} .2014$. Phylogeny of harvestmen family Gonyleptidae inferred from a multilocus approach (Arachnida: Opiliones). Cladistics 30:519-539.

Rambla, M. 1978. Systematics of Laniatorid Opiliones. Symposium of the Zoological Society of London 42:303-307.

Roewer, C. F. 1913. Die Familie der Gonyleptiden der OpilionesLaniatores. Archiv für Naturgeschichte 79A:1-472.

1915. 106 neue Opilioniden. Archiv für Naturgeschichte abt. A 81A:1-152.

. 1923. Die Weberknechte der Erde. Systematische Bearbeitung der bisher bekannten Opiliones. Jena, Gustav-Ficher. 1116p. . 1929. Weitere Weberknechte III. III. Ergänzung der: "Weberknechte der Erde", 1923. Abhandlungen Naturwissenschaftlichen Verein zu Bremen 27:179-284.

Sonres, B. A. M. 1945a. Opiliões do Paraná. Arquivos do Museu Paranaense 4:191-206.

. 1945b. Opiliões da coleção do Museu Nacional do Rio de Janeiro. Arquivos de Zoologia do Estado de São Paulo 4:341-394.
Sotres, B. A. M. \& SoAres, H. E. M. 1945. Mais opiliões pertencentes ao Museu Paranaense. Revista Agricultura de Piracicaba 20:365-377. 1947a. Alótipos e formas novas de opiliões paranaenses (Opiliones - Gonyleptidae, Phalangiidae). Papéis Avulsos do Departamento de Zoologia 8: 63-84.

1947b. Opiliões pertencentes à coleção Gert Hatschbach. Papéis Avulsos do Departamento de Zoologia 8:209-230.

1954. Monografia dos gêneros de opiliões neotrópicos III. Arquivos de Zoologia do Estado de São Paulo 8:225-302.

SoAres, H. E. M. 1966a. Opiliões da coleção Gofferjè (Opiliones: Gonyleptidae, Phalangodidae). Papéis Avulsos do Departamento de Zoologia 18:87-102.

1966b. Opiliões pertencentes à coleção "Eugenio W. Gruman" (Opiliones: Cosmetidae, Gonyleptidae). Papéis avulsos do Departamento de Zoologia 18:117-123.

TAVAres, M. L. R. 1980. Novas ocorrências de opiliões no Rio Grande do Sul e descrição da fêmea de Melloleitaniana riodariensis Soares \& Soares, 1945 (Gonyleptidae). Iheringia, Série Zoologia (55):155-159.

Weidner, H. 1959. Die entomologischen Sammlungen des Zoologischen Staatsinstitut und Zoologischen Museum Hamburg. I. Teil. Pararthropoda und Chelicerata I. Mitteilungen aus dem Hamburgischen Zoologischen Museum und Institut 57:89-142. 